\title{
Ultrasound-Assisted Synthesis of Luminescent Micro- and Nanocrystalline Eu-Based MOFs as Luminescent Probes for Heavy Metal Ions
}

\author{
Stefaniia S. Kolesnik ${ }^{1}$, Viktor G. Nosov ${ }^{1}$, Ilya E. Kolesnikov ${ }^{1}$, Evgenia M. Khairullina ${ }^{1}$, Ilya I. Tumkin ${ }^{1}$, \\ Aleksandra A. Vidyakina ${ }^{1}$, Alevtina A. Sysoeva ${ }^{2}$, Mikhail N. Ryazantsev ${ }^{1,3} \mathbb{D}_{\text {, Maxim S. Panov }}{ }^{1}$, \\ Vasiliy D. Khripun ${ }^{1}$, Nikita A. Bogachev ${ }^{1}$, Mikhail Yu. Skripkin ${ }^{1}$ and Andrey S. Mereshchenko ${ }^{1,2, *(D)}$ \\ check for \\ updates \\ 1 Saint-Petersburg State University, 7/9 Universitetskaya emb., 199034 St. Petersburg, Russia; \\ staphylinuscaesareus@gmail.com (S.S.K.); nosoff.vitia2018@yandex.ru (V.G.N.); \\ ilya.kolesnikov@spbu.ru (I.E.K.); iskint@mail.ru (E.M.K.); i.i.tumkin@spbu.ru (I.I.T.); \\ vidyakina.aleksandra@mail.ru (A.A.V.); mikhail.n.ryazantsev@gmail.com (M.N.R.); \\ m.s.panov@spbu.ru (M.S.P.); v.khripun@spbu.ru (V.D.K.); allanfrack@yandex.ru (N.A.B.); \\ skripkin1965@yandex.ru (M.Y.S.) \\ 2 Sirius University of Science and Technology, 1 Olympic Ave, 354340 Sochi, Russia; sysoevaaa_04@mail.ru \\ 3 Laboratory of Nanobiotechnology, Saint Petersburg Academic University, ul. Khlopina 8/3, \\ 194021 St. Petersburg, Russia \\ * Correspondence: a.mereshchenko@spbu.ru; Tel.: +7-951-677-5465
}

Citation: Kolesnik, S.S.; Nosov, V.G.; Kolesnikov, I.E.; Khairullina, E.M.; Tumkin, I.I.; Vidyakina, A.A.; Sysoeva, A.A.; Ryazantsev, M.N.; Panov, M.S.; Khripun, V.D.; et al. Ultrasound-Assisted Synthesis of Luminescent Micro- and

Nanocrystalline Eu-Based MOFs as Luminescent Probes for Heavy Metal Ions. Nanomaterials 2021, 11, 2448. https://doi.org/10.3390/nano11092448

Academic Editors: Marcin Runowski and Guoping Dong

Received: 26 July 2021

Accepted: 16 September 2021

Published: 20 September 2021

Publisher's Note: MDPI stays neutral with regard to jurisdictional claims in published maps and institutional affiliations.

Copyright: (C) 2020 by the authors. Licensee MDPI, Basel, Switzerland. This article is an open access article distributed under the terms and conditions of the Creative Commons Attribution (CC BY) license (https:/ / creativecommons.org/licenses/by/ $4.0 /)$.
Abstract: The luminescent coarse-, micro- and nanocrystalline europium(III) terephthalate tetrahydrate $\left(\mathrm{Eu}_{2} \mathrm{bdc}_{3} \cdot 4 \mathrm{H}_{2} \mathrm{O}\right)$ metal-organic frameworks were synthesized by the ultrasound-assisted wetchemical method. Electron micrographs show that the europium(III) terephthalate microparticles are $7 \mu \mathrm{m}$ long leaf-like plates. According to the dynamic light scattering technique, the average size of the $\mathrm{Eu}_{2} \mathrm{bdc}_{3} \cdot 4 \mathrm{H}_{2} \mathrm{O}$ nanoparticles is equal to about $8 \pm 2 \mathrm{~nm}$. Thereby, the reported $\mathrm{Eu}_{2} \mathrm{bdc}_{3} \cdot 4 \mathrm{H}_{2} \mathrm{O}$ nanoparticles are the smallest nanosized rare-earth-based MOF crystals, to the best of our knowledge. The synthesized materials demonstrate red emission due to the ${ }^{5} \mathrm{D}_{0}-{ }^{7} \mathrm{~F}_{\mathrm{J}}$ transitions of $\mathrm{Eu}^{3+}$ upon $250 \mathrm{~nm}$ excitation into ${ }^{1} \pi \pi^{*}$ state of the terephthalate ion. Size reduction results in broadened emission bands, an increase in the non-radiative rate constants and a decrease in both the quantum efficiency of the ${ }^{5} \mathrm{D}_{0}$ level and $\mathrm{Eu}^{3+}$ and the luminescence quantum yields. $\mathrm{Cu}^{2+}, \mathrm{Cr}^{3+}$, and $\mathrm{Fe}^{3+}$ ions efficiently and selectively quench the luminescence of nanocrystalline europium(III) terephthalate, which makes it a prospective material for luminescent probes to monitor these ions in waste and drinking water.

Keywords: metal-organic framework; luminescence; rare earth; europium; nanoparticle; luminescent probe

\section{Introduction}

Rare-earth-based metal-organic frameworks (MOFs) are actively used in various fields of science and technology as luminescent sensors [1-11], LED components [12], luminescent probes for bioimaging [13,14], and luminescent thermometers [15,16]. Small-sized crystals of the rare-earth-based MOFs are especially interesting due to their unique properties. Such materials have a large specific surface area, and as a result, they can effectively adsorb other ions and molecules, which is necessary for the development of sensitive luminescent sensors [17-19]. The presence of heavy metals in drinking water can cause numerous disorders and diseases of humans and animals [20,21]. Therefore, one must develop new sensors for such pollutants. MOFs are actively used as luminescent and electrochemical sensors for heavy metal ion detection in drinking and wastewater $[1-3,6,7,10]$. Nanosized luminescent MOFs are able to penetrate the cell membrane and are therefore used in bioimaging as luminescent probes $[13,14]$. The nano-sized rare-earth-based MOFs can be synthesized by several synthetic routes [13,14,22-25] such as solvothermal, reverse 
microemulsion, surfactant-assisted, microwave, and ultrasonic methods. The resulting small-sized particles usually have sizes from 40 to $5000 \mathrm{~nm}$.

In our current study, we report the room-temperature ultrasonic-assisted wet chemical method of the synthesis of the small-sized luminescent $\mathrm{Eu}_{2} \mathrm{bdc}_{3} \cdot 4 \mathrm{H}_{2} \mathrm{O}$ MOFs including $8 \mathrm{~nm}$ nanoparticles - the smallest nanosized rare-earth-based MOF crystals, to the best of our knowledge. The luminescent properties of the coarse-, micro- and nanocrystalline europium(III) terephthalate are studied. In addition, the selective luminescence quenching by heavy metal ions is also reported.

\section{Materials and Methods}

\subsection{Reagents}

Europium chloride hexahydrate was purchased from Chemcraft (Russia). Benzene1,4-dicarboxylic (terephthalic, $\mathrm{H}_{2}$ bdc) acid ( $>98 \%$ ) sodium hydroxide $(>99 \%)$, polyethylene glycol 6000 (PEG-6000, for synthesis), iron(III) chloride hexahydrate (>99\%), iron(II) sulphate heptahydrate $(>99 \%)$, chromium(III) chloride hexahydrate $(>99 \%)$, magnesium chloride hexahydrate ( $>99 \%)$, nickel(II) chloride hexahydrate (>99\%), lead(II) nitrate ( $>99 \%)$, cobalt(II) chloride hexahydrate ( $>99 \%)$, anhydrous zinc chloride $(>98 \%)$, cadmium chloride hydrate $(>98 \%)$, barium chloride dihydrate $(>99 \%)$, copper(II) chloride dihydrate $(>99 \%)$, and EDTA disodium salt (0.1M aqueous solution) were purchased from Sigma-Aldrich Pty Ltd. (Germany) and used without additional purification. The $0.2 \mathrm{M}$ solutions of the above-mentioned salts were prepared and standardized by complexometric titration with EDTA. An amount of 0.3 moles of the terephthalic acid and 0.6 moles of the sodium hydroxide were dissolved in the distilled water to obtain $1 \mathrm{~L}$ of $0.3 \mathrm{M}$ solution of the disodium terephthalate $\left(\mathrm{Na}_{2} \mathrm{bdc}\right)$.

\subsection{Synthesis}

The europium(III) terephthalate was obtained by mixing the $\mathrm{EuCl}_{3}$ and $\mathrm{Na}_{2}$ bdc solutions. Sample 1 was synthesized by a slow mixing of equal volumes of the $2 \mathrm{mM} \mathrm{Na}_{2} \mathrm{bdc}$ and $1 \mathrm{mM} \mathrm{EuCl}{ }_{3}$ solutions accompanied by vigorous stirring (Table 1). Sample 2 was synthesized by a slow mixing of the equal volumes of the $2 \mathrm{mM} \mathrm{Na}_{2}$ bdc solution and the solution containing $1 \mathrm{mM} \mathrm{EuCl}_{3}$ and $20 \%$ PEG-6000, accompanied by ultrasonication $(40 \mathrm{kHz}, 60 \mathrm{~W})$ and vigorous stirring. The white precipitates of europium(III) terephthalate (Samples 1 and 2) were separated from the reaction mixture by centrifugation $(4000 \times g)$ and washed with deionized water 5 times. Sample 3 was synthesized by a slow mixing of equal volumes of $1 \mathrm{mM} \mathrm{Na} 2 \mathrm{bdc}$ and $0.5 \mathrm{mM} \mathrm{EuCl}_{3}$ accompanied by ultrasonication $(40 \mathrm{kHz}$, $60 \mathrm{~W}$ ) and vigorous stirring. The obtained clear solution was centrifugated at $7500 \times g$; however, no solid was precipitated. The addition of both polar (methanol and acetone) and non-polar solvents (ethanol-dichloromethane mixture) did not result in the salting-out of any solid. Therefore, we used the solution of Sample 3 in the further experiments. All experiments were performed at the temperature of $25^{\circ} \mathrm{C}$.

Table 1. Overview of the synthesis of europium(III) terephthalates 1-3.

\begin{tabular}{cccccc}
\hline Sample & $\mathbf{C}\left(\mathrm{EuCl}_{3}\right)$ & $\mathbf{C}\left(\mathrm{Na}_{\mathbf{2}} \mathbf{b d c}\right)$ & PEG-6000 & Ultrasonication & Stirring \\
\hline $\mathbf{1}$ & $1 \mathrm{mM}$ & $2 \mathrm{mM}$ & - & - & + \\
$\mathbf{2}$ & $1 \mathrm{mM}$ & $2 \mathrm{mM}$ & $20 \%$ & + & + \\
$\mathbf{3}$ & $0.5 \mathrm{mM}$ & $1 \mathrm{mM}$ & - & + & + \\
\hline
\end{tabular}

\subsection{Characterization}

The morphologies of the microstructures of the synthesized Samples $\mathbf{1}$ and $\mathbf{2}$ were characterized using scanning electron microscopy (SEM) with a Zeiss Merlin electron microscope (Zeiss, Germany) equipped with the energy-dispersive X-ray spectroscopy (EDX) module (Oxford Instruments INCAx-act, UK). X-ray powder diffraction (XRD) measurements were performed on a D2 Phaser (Bruker, USA) X-ray diffractometer using $\mathrm{Cu} \mathrm{K} \alpha$ 
radiation $(\lambda=1.54056 \AA)$. The particle size distribution of the aqueous solution of Sample 3 was revealed by the dynamic light scattering technique with an SZ-100 Series Nanoparticle Analyzer (Horiba Jobin Yvon, Japan) The luminescence spectra were recorded with a Fluorolog-3 fluorescence spectrometer (Horiba Jobin Yvon, Japan). Lifetime measurements were performed with the same spectrometer using a pulsed Xe lamp (pulse duration $3 \mu \mathrm{s}$ ). The absolute values of the photoluminescence quantum yields were recorded using a Fluorolog 3 Quanta-phi device. All measurements were performed at the temperature of $25^{\circ} \mathrm{C}$.

\section{Results and Discussion}

\subsection{Morphology}

A scanning electron microscope was used to observe the shape and the size of the particles in the synthesized materials. Sample 1, which was synthesized by a slow mixing of equal volumes of sodium terephthalate $(2 \mathrm{mM})$ and europium chloride $(1 \mathrm{mM})$ aqueous solutions, precipitated in the form of a polycrystalline solid with the average particle size of $120 \pm 30 \mu \mathrm{m}$ (Figure 1). The observed species consisted of smaller particles stacked together forming dendrimer-like microparticle assemblies. The addition of the non-ionic surfactant (PEG-6000) to the reaction mixture and ultrasonication without a change in the $\mathrm{Eu}^{3+}$ and $\mathrm{bdc}^{2-}$ concentrations (Sample 2) prevented the aggregation of the microparticles and resulted in the formation of individual microparticles (Figure 2a-c). The particles had a leaf-like shape with ratio length:width:height of about 13:5:1. The particles size was obtained from SEM images, the particle size distribution is shown in Figure 2d,e. The average length and width were calculated from these distributions and are equal to $7.1 \pm 1.6$ and $2.8 \pm 0.8 \mu \mathrm{m}$, respectively. We found that under ultrasonication the solution remained clear to the eye when the concentration of $\mathrm{Eu}^{3+}$ and $\mathrm{bdc}^{2-}$ was decreased twofold $\left(1 \mathrm{mM} \mathrm{Na}_{2} \mathrm{bdc}\right.$ and $\left.0.5 \mathrm{mM} \mathrm{EuCl}_{3}\right)$ both in the absence and the presence of the surfactant (PEG-6000). We could not precipitate the solid from the reaction mixture using high-speed centrifugation or by salting-out using organic solvents. Therefore, the formation of the nano-sized particles of europium(III) terephthalate was supposed. In order to exclude the contribution of the PEG micelles to the experimental data, in further experiments we carefully studied the aqueous suspension of Sample 3 obtained by a slow mixing of equal volumes of the $1 \mathrm{mM} \mathrm{Na} 2$ bdc and $0.5 \mathrm{mM} \mathrm{EuCl}_{3}$ accompanied by ultrasonication and vigorous stirring without a PEG-6000 addition. The particle size distribution was revealed by a dynamic light scattering technique, resulting in the average particle size equal to about $8 \pm 2 \mathrm{~nm}$ (Figure 3). The SEM-EDX study of 3 aggregates formed by drying the reaction mixture on the silicon plate revealed the presence of Eu in the sample but did not determine the particle size due to the insufficient spatial resolution of the used SEM microscope. The direct observation of the species using TEM was also problematic because the high-energy electron radiation $(>100 \mathrm{kV})$ burned out the sample due to the decomposition of an organic linker (terephthalate ion).

In our study, we have found that ultrasonication and PEG-6000 addition significantly decreases the particle size and prevents aggregation. The increase in particle size can be achieved via continuous growth of a particle or gradual aggregation of various particles or seed crystals. The contact of particles can reduce the total surface area in the aggregation process resulting in overall energy reduction. Ultrasonication can encourage surface tension between the species caused by the acoustic radiation force on a compressible particle [26]. The effect of PEG addition on the particle size can be explained by the well-known properties of surfactants including polyethylene glycol to be adsorbed on the particles or seed crystals that decrease their surface energy and prevents aggregation [27-29]. Surprisingly, we revealed that the twofold decrease in the reagents' concentration leads to size reduction for several orders. A recent kinetic study of zinc-2-methylimidazole MOF ZIF-8 [30] reported that nucleation and crystal growth rates non-monotonously depend on the concentration of the reagents. During the low concentrations of the metal ions and the organic linker, the 1:1 M:L complex dominates. This state is called the "pre-equilibrium". 
Further nucleation is associative and fast because the central atom has several weakly coordinated solvent molecules and can easily react with other 1:1 complexes resulting in the formation of oligomeric secondary building units (SBUs) [31]. Increasing the concentration of the metal ions and the organic linker leads to the domination of 1:2 and 1:3 M:L complexes. The aggregation of 1:2 and 1:3 M:L complexes into SBUs is slower than 1:1 complexes, which results in slower nucleation. Therefore, nucleation is faster than the growth process in solutions containing low concentrations of the metal ions and the organic linker, which explains the formation of the smaller particle size of the MOFs crystallizing at low concentrations.

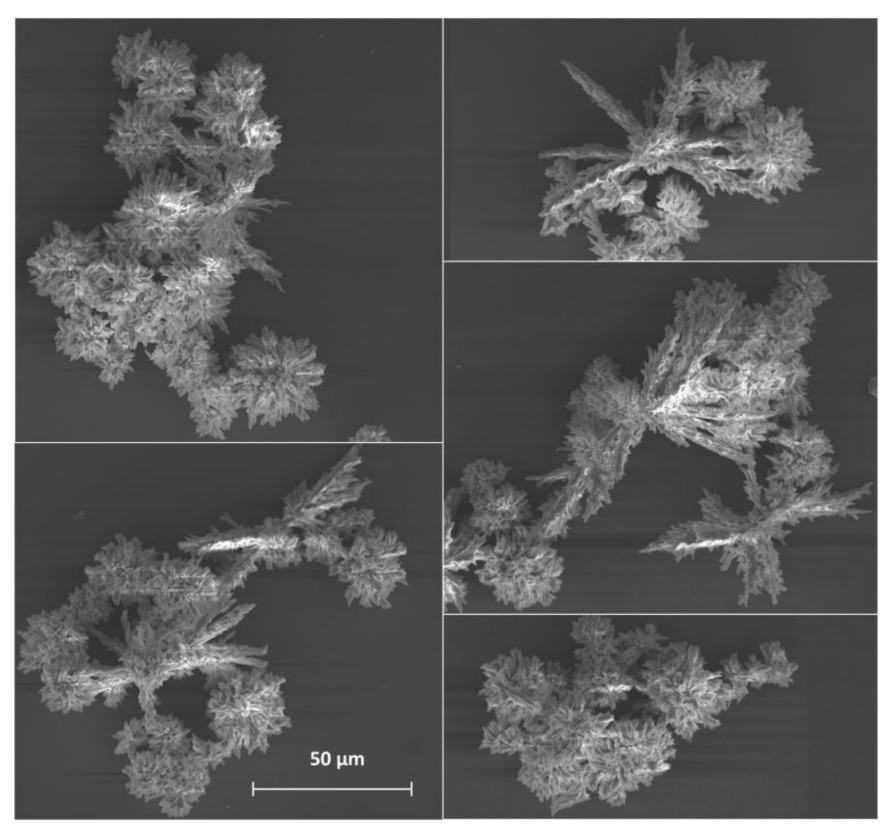

Figure 1. SEM images of Sample 1. The average diameter of polycrystals is $120 \pm 30 \mu \mathrm{m}$.

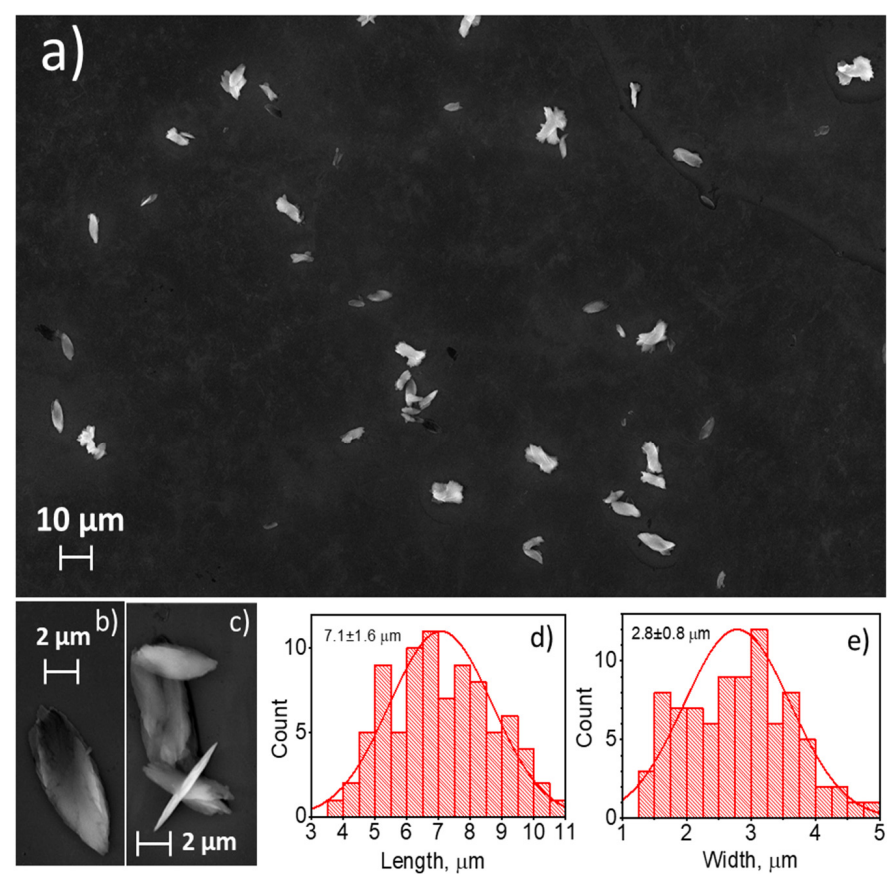

Figure 2. SEM images of Sample 2 (panels a-c). Particle size distribution (length and width) is shown in panels $(\mathbf{d}, \mathbf{e})$. The particles have the shape of the elliptic plates with ratio length:width:height of about 13:5:1. The average length and width were found to be equal to $7.1 \pm 1.6$ and $2.8 \pm 0.8 \mu \mathrm{m}$, respectively. 


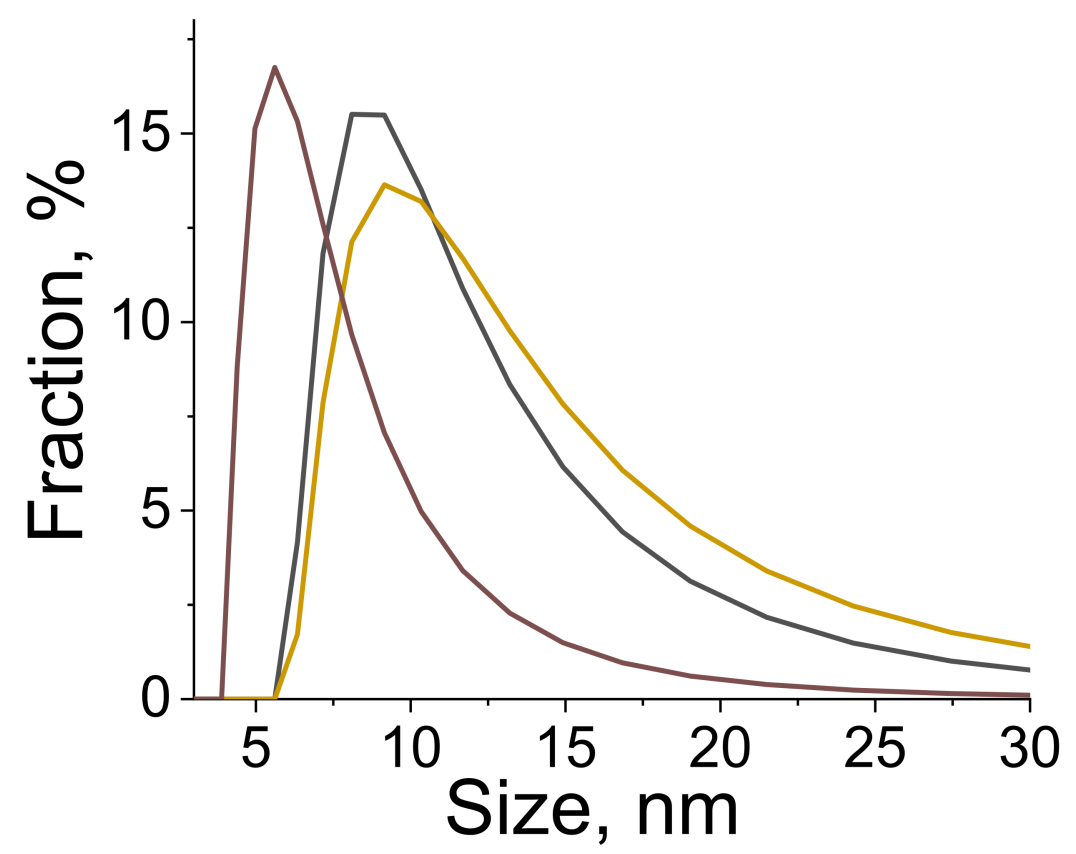

Figure 3. The particle size distribution of the aqueous solution of 3 is revealed by dynamic light scattering as a result of three parallel measurements. The average particle size is equal to about $8 \pm 2 \mathrm{~nm}$ (spherical approximation).

\subsection{Crystal Structure}

The X-ray powder diffraction (XRD) patterns were measured (Figure 4) for Samples 1 and 2 to discover the crystalline phase of the obtained materials. We could not precipitate Sample 3 from the solution; therefore, the XRD pattern of Sample 3 was not measured. Analysis of XRD patterns demonstrated that synthesized materials $\mathbf{1}$ and $\mathbf{2}$ are isostructural with the $\mathrm{Tb}_{2} \mathrm{bdc}_{3} \cdot 4 \mathrm{H}_{2} \mathrm{O}$ [32], the typical crystalline phase of lanthanide terephthalates [22], which indicated that materials 1 and 2 were obtained in a form of $\mathrm{Eu}_{2} b \mathrm{bdc}_{3} \cdot 4 \mathrm{H}_{2} \mathrm{O}$. This structure is a three-dimensional metal-organic framework (MOF), where octacoordinated $\mathrm{Eu}^{3+}$-ions are bound to the two water molecules and six terephthalate ions through the oxygen atoms (Figure 4). XRD peaks of $\mathrm{Eu}_{2} \mathrm{bdc}_{3} \cdot 4 \mathrm{H}_{2} \mathrm{O}$ in Samples $\mathbf{1}$ and 2 slightly diverge from their counterparts measured for $\mathrm{Tb}_{2} \mathrm{bdc}_{3} \cdot 4 \mathrm{H}_{2} \mathrm{O}$ reported previously [32]. To compare the structures of $\mathrm{Eu}_{2} \mathrm{bdc}_{3} \cdot 4 \mathrm{H}_{2} \mathrm{O}$ and $\mathrm{Tb}_{2} \mathrm{bdc}_{3} \cdot 4 \mathrm{H}_{2} \mathrm{O}$ materials, the refinement of unit cell parameters was performed for the $\mathrm{Eu}_{2} \mathrm{bdc}_{3} \cdot 4 \mathrm{H}_{2} \mathrm{O}$ samples (Table 2). One can observe that the structure of coarse-crystalline $\mathrm{Eu}_{2} \mathrm{bdc}_{3} \cdot 4 \mathrm{H}_{2} \mathrm{O}(\mathbf{1})$ is slightly different from that of $\mathrm{Tb}_{2} \mathrm{bdc}_{3} \cdot 4 \mathrm{H}_{2} \mathrm{O}$. The ionic radius of the octacoordinated $\mathrm{Eu}^{3+}$ ion $(1.066 \AA)$ is slightly larger than that of the octacoordinated $\mathrm{Tb}^{3+}$ ion $(1.040 \AA$ ) [33], which most likely results in minor differences between $\mathrm{Eu}_{2} \mathrm{bdc}_{3} \cdot 4 \mathrm{H}_{2} \mathrm{O}$ and $\mathrm{Tb}_{2} \mathrm{bdc}_{3} \cdot 4 \mathrm{H}_{2} \mathrm{O}$ structures. The unit cell parameters of microcrystalline $\mathrm{Eu}_{2} \mathrm{bdc}_{3} \cdot 4 \mathrm{H}_{2} \mathrm{O}(2)$ are somewhat different, both from that of coarse-crystalline $\mathrm{Eu}_{2} \mathrm{bdc}_{3} \cdot 4 \mathrm{H}_{2} \mathrm{O}(\mathbf{1})$ and $\mathrm{Tb}_{2} \mathrm{bdc}_{3} \cdot 4 \mathrm{H}_{2} \mathrm{O}$ [32], which is likely caused by the surface defects due to the relatively small particle size of several micrometers.

Table 2. Unit cell parameters for $\mathrm{Tb}_{2} \mathrm{bdc}_{3} \cdot 4 \mathrm{H}_{2} \mathrm{O}$ [32] and $\mathrm{Eu}_{2} \mathrm{bdc}_{3} \cdot 4 \mathrm{H}_{2} \mathrm{O}$ (Samples 1 and 2).

\begin{tabular}{cccccccc}
\hline Sample & $\mathbf{a}, \mathbf{\AA}$ & $\mathbf{b}, \mathbf{\AA}$ & $\mathbf{c}, \AA$ & $\boldsymbol{\alpha}, \mathbf{d e g}$. & $\boldsymbol{\beta}, \mathbf{d e g}$. & $\boldsymbol{\gamma}, \mathbf{d e g}$. & $\mathbf{V}, \AA^{\mathbf{3}}$ \\
\hline $\mathrm{Tb}_{2} \mathrm{bdc}_{3} \cdot 4 \mathrm{H}_{2} \mathrm{O}$ & 6.14 & 10.07 & 10.10 & 102.25 & 91.12 & 101.52 & 596.63 \\
$\mathrm{Eu}_{2} \mathrm{bdc}_{3} \cdot 4 \mathrm{H}_{2} \mathrm{O}(\mathbf{1})$ & 6.20 & 9.85 & 10.29 & 102.15 & 89.75 & 105.10 & 592.91 \\
$\mathrm{Eu}_{2} \mathrm{bdc}_{3} \cdot 4 \mathrm{H}_{2} \mathrm{O}(\mathbf{2})$ & 6.16 & 9.8 & 10.22 & 101.84 & 90.27 & 104.86 & 582.19 \\
\hline
\end{tabular}



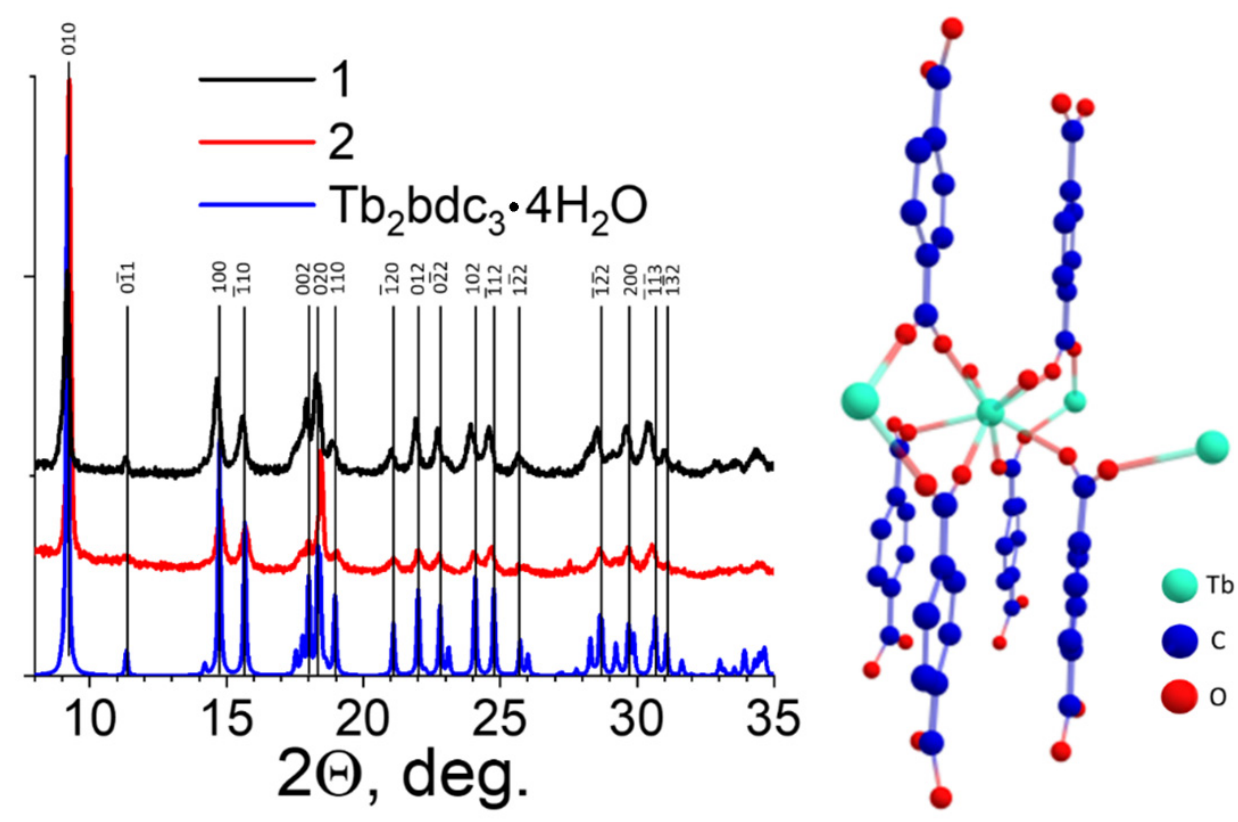

Figure 4. The XRD patterns of europium(III) terephthalate powders (1 and 2 ) and the simulated XRD pattern of $\mathrm{Tb}_{2} \mathrm{bdc}_{3} \cdot 4 \mathrm{H}_{2} \mathrm{O}$ single-crystal structure taken from ref. [32] and the crystal structure of $\mathrm{Tb}_{2} \mathrm{bdc}_{3} \cdot 4 \mathrm{H}_{2} \mathrm{O}$.

\subsection{Luminescent Properties}

Terephthalate ions are known to intensively absorb ultraviolet light, promoting them into the ${ }^{1} \pi \pi^{*}$ singlet electronic excited state [32,34,35]. In europium(III) terephthalate, the ${ }^{1} \pi \pi^{*}$ state efficiently undergoes the ${ }^{3} \pi \pi^{*}$ triplet electronic excited state by intersystem crossing due to the heavy atom effect [35] followed by an energy transfer to ${ }^{5} \mathrm{D}_{1}$ level of the $\mathrm{Eu}^{3+}$ ion, due to relatively close energy values of the lowest energy ${ }^{3} \pi \pi^{*}$ excited state of terephthalate ion [35] $\left(\approx 20,000 \mathrm{~cm}^{-1}\right)$ and ${ }^{5} \mathrm{D}_{1}$ level of $\mathrm{Eu}^{3+}$ ion $[36]\left(\approx 19,000 \mathrm{~cm}^{-1}\right)$. ${ }^{5} \mathrm{D}_{1}$ level of the $\mathrm{Eu}^{3+}$ ion [36] then undergoes internal conversion followed by emission corresponding to ${ }^{5} \mathrm{D}_{0}-{ }^{7} \mathrm{~F}_{\mathrm{J}}(\mathrm{J}=0-5)$ transitions. Figure 5 a presents the emission spectra of the europium(III) terephthalate series (1-3) upon $250 \mathrm{~nm}$ excitation into the ${ }^{1} \pi \pi^{*}$ singlet electronic excited state of the terephthalate ion. The emission spectra include narrow lines corresponding to the transitions from excited ${ }^{5} \mathrm{D}_{0}$ to lower ${ }^{7} \mathrm{~F}_{\mathrm{J}}$ levels: ${ }^{5} \mathrm{D}_{0}-{ }^{7} \mathrm{~F}_{0}(578 \mathrm{~nm}),{ }^{5} \mathrm{D}_{0}-{ }^{7} \mathrm{~F}_{1}(590 \mathrm{~nm})$, ${ }^{5} \mathrm{D}_{0}-{ }^{7} \mathrm{~F}_{2}(615 \mathrm{~nm}),{ }^{5} \mathrm{D}_{0}-{ }^{7} \mathrm{~F}_{3}(649 \mathrm{~nm})$, and ${ }^{5} \mathrm{D}_{0}-{ }^{7} \mathrm{~F}_{4}(697 \mathrm{~nm})$. The emission spectrum of nanocrystalline 3 also contains spectrally broad band peaking at about $420 \mathrm{~nm}$, which corresponds to the terephthalate phosphorescence [35]. The most prominent transitions in the emission spectra are magnetic dipole ${ }^{5} \mathrm{D}_{0}-{ }^{7} \mathrm{~F}_{1}$ and forced electric dipole ${ }^{5} \mathrm{D}_{0}{ }^{-}{ }^{7} \mathrm{~F}_{2}$ and ${ }^{5} \mathrm{D}_{0}-{ }^{7} \mathrm{~F}_{4}$ transitions. The excitation spectrum $\left(\lambda_{\mathrm{em}}=615 \mathrm{~nm}\right)$ of nanocrystalline 3 resembles its UV-Vis absorption spectrum (Figure $5 \mathrm{~b}$ ) consisting of a $250 \mathrm{~nm}$ band as well as a $280 \mathrm{~nm}$ shoulder corresponding to the transitions into ${ }^{1} \pi \pi^{*}$ singlet electronic excited states of the terephthalate ion. One can notice that emission bands corresponding to the $\mathrm{f}-\mathrm{f}$ transitions of the $\mathrm{Eu}^{3+}$ ion significantly broaden with the particle size reduction. Thus, the ${ }^{5} \mathrm{D}_{0}-{ }^{7} \mathrm{~F}_{2}$ band of coarse-crystalline 1 , microcrystalline 2 , and nanocrystalline 3 have full width at half maximum (fwhm) equal to 48,66 , and $238 \mathrm{~cm}^{-1}$, respectively. The smaller particles have larger surface-to-volume ratio and the number of structural defects, which results in a larger dispersion of energies of electronic levels of $\mathrm{Eu}^{3+}$ ions caused by the larger non-uniformity of the local environment of europium ions $[37,38]$. The luminescence decay curves of europium(III) terephthalate (Figure $5 c$ ) are fitted by single-exponential functions:

$$
I_{l u m}(t)=I_{o} e^{-\frac{t}{\tau_{f}}}
$$


where time constant $\tau_{f}$ corresponds to the observed lifetime of ${ }^{5} \mathrm{D}_{0}$ level. The observed lifetime of ${ }^{5} \mathrm{D}_{0}$ level of coarse-crystalline $\mathbf{1}$, microcrystalline 2 , and nanocrystalline 3 were found to be equal to $393 \pm 3,371 \pm 4$, and $115 \pm 2 \mu$ s, respectively.
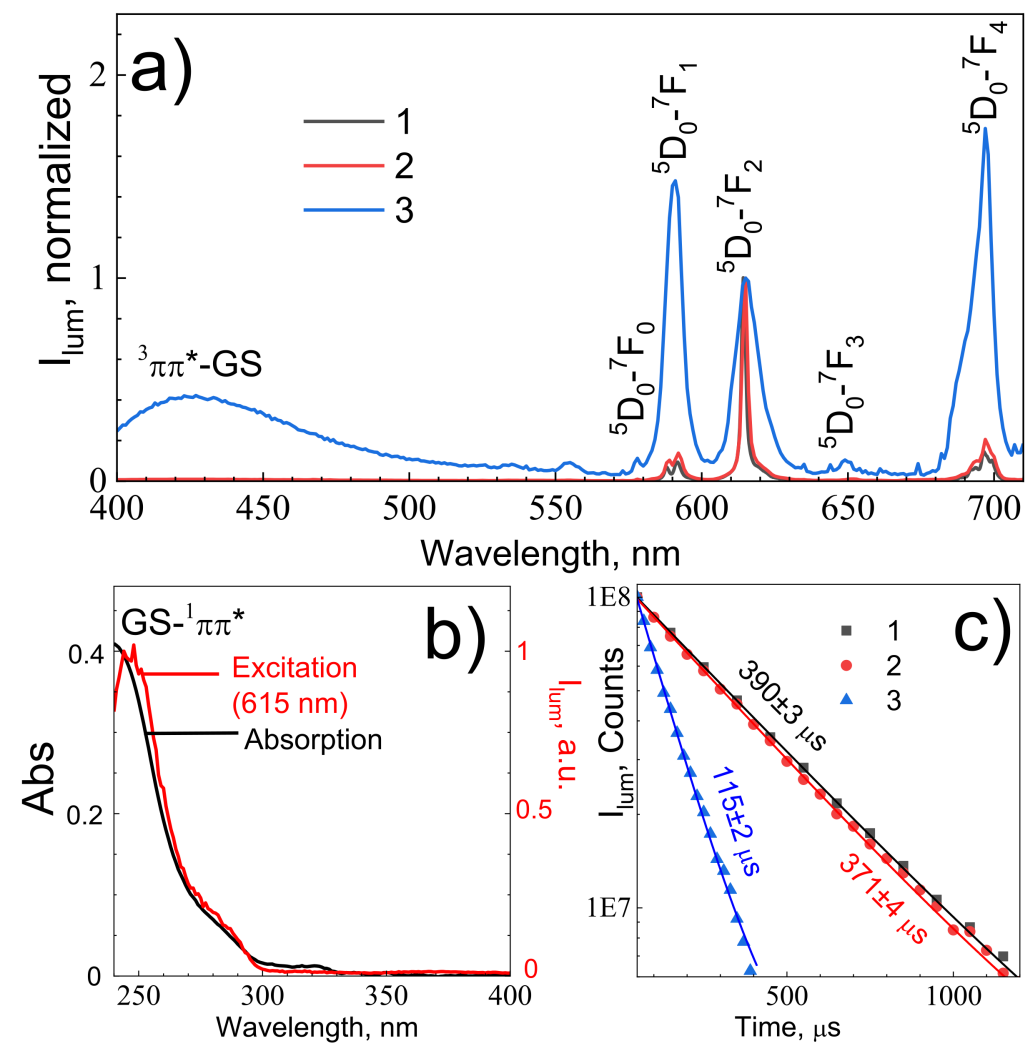

Figure 5. (a) The emission spectra of europium(III) terephthalate samples of different sized particles $\left(\lambda_{\mathrm{ex}}=250 \mathrm{~nm}\right)$ normalized at the $615 \mathrm{~nm}$ emission band intensity. Sample numbers are shown in legend; (b) absorption (black line) and excitation (red line, $\lambda_{\mathrm{em}}=615 \mathrm{~nm}$ ) spectra of aqueous solution europium(III) terephthalate nanoparticles 3; (c) $615 \mathrm{~nm}$ luminescence decay curves of europium(III) terephthalate samples of different sized particles.

Luminescence decay is affected by the combination of radiative and nonradiative processes. Radiative decay rate is determined by dipole transition strength and localfield correction. Nonradiative processes include multi-phonon relaxation, quenching on impurities (e.g., O-H group of water molecules) and cooperative processes (cross-relaxation, energy migration). Detailed descriptions of these processes were provided in our earlier papers $[39,40]$. The radiative and nonradiative decay rates of $\mathrm{Eu}^{3+}$-doped phosphors can be calculated from the emission spectrum using $4 \mathrm{f}-4 \mathrm{f}$ intensity theory [41]. Magnetic dipole ${ }^{5} \mathrm{D}_{0}-{ }^{7} \mathrm{~F}_{1}$ transition probability $\mathrm{A}_{0-1}=\mathrm{A}_{\mathrm{MD}, 0} \cdot \mathrm{n}_{0}{ }^{3}=14.65 \cdot 1.5^{3}=49 \mathrm{~s}^{-1} . \mathrm{A}_{\mathrm{MD}, 0}$ is the spontaneous emission probability of the magnetic dipole ${ }^{5} \mathrm{D}_{0}-{ }^{7} \mathrm{~F}_{1}, 14.65 \mathrm{~s}^{-1}$, and $\mathrm{n}_{0}$ is the refractive index, 1.5 [34]. Radiative decay rates $\mathrm{A}_{0-\lambda}(\lambda=2,4)$ of the ${ }^{5} \mathrm{D}_{0}-{ }^{7} \mathrm{~F}_{\lambda}$ emission transition can be obtained from this formula:

$$
A_{0-\lambda}=A_{0-1} \frac{v_{0-1}}{v_{0-\lambda}} \frac{\mathrm{I}_{0-\lambda}}{\mathrm{I}_{0-1}}
$$

where $\mathrm{I}_{0-\lambda}$ and $v_{0-\lambda}$ are the integral intensity and frequency of the ${ }^{5} \mathrm{D}_{0}-{ }^{7} \mathrm{~F}_{\lambda}$ emission transition. The total radiative decay rate, $\mathrm{A}_{\mathrm{r}}$, could be calculated by summing all the $\mathrm{A}_{0-\lambda}$ radiative decay rates $(\lambda=1,2,4)$. The total decay rate is reciprocal to the observed lifetime of ${ }^{5} \mathrm{D}_{0}$ level, shown in Figure $5 \mathrm{c}, A_{\text {total }}=\frac{1}{\tau_{f}}$, whereas the nonradiative probability can be calculated as: $A_{n r}=A_{\text {total }}-A_{r}$. Quantum efficiency of ${ }^{5} \mathrm{D}_{0}$ level is $\eta=\frac{A_{r}}{A_{\text {total }}}$. Decay 
rates and quantum efficiencies of the ${ }^{5} \mathrm{D}_{0}$ level of europium(III) terephthalates $1-3$ are summarized in Table 3.

Table 3. Radiative $\left(\mathbf{A}_{\mathbf{r}}\right)$, nonradiative $\left(\mathbf{A}_{\mathbf{n r}}\right)$ and total $\left(\mathbf{A}_{\text {total }}\right)$ decay rates, quantum efficiencies ( $\left.\boldsymbol{\eta}\right)$ of the ${ }^{5} \mathrm{D}_{0}$ level of europium(III) and $\mathrm{Eu}^{3+}$ luminescence quantum yields ( $\boldsymbol{\Phi}$ ) upon excitation into ${ }^{1} \pi \pi^{*}$ singlet electronic excited state of terephthalate ion terephthalates 1-3.

\begin{tabular}{cccccc}
\hline Sample & $\mathbf{A}_{\mathbf{r}}\left(\mathbf{s}^{-\mathbf{1}}\right)$ & $\mathbf{A}_{\mathbf{n r}}\left(\mathbf{s}^{-\mathbf{1}}\right)$ & $\mathbf{A}_{\text {total }}\left(\mathbf{s}^{-\mathbf{1}}\right)$ & $\boldsymbol{\eta} \mathbf{( \% )}$ & $\boldsymbol{\Phi} \mathbf{( \% )}$ \\
\hline $\mathbf{1}$ & 371 & 2193 & 2564 & 14.5 & $10 \pm 1$ \\
$\mathbf{2}$ & 290 & 2405 & 2695 & 10.8 & $5 \pm 1$ \\
$\mathbf{3}$ & 150 & 8545 & 8695 & 1.7 & $1.5 \pm 0.5$ \\
\hline
\end{tabular}

Analyzing Table 2, one can see the quantum efficiencies of the ${ }^{5} \mathrm{D}_{0}$ level and $\mathrm{Eu}^{3+}$ luminescence quantum yields decrease in series 1-3 simultaneously with particle size, whereas nonradiative decay rate constants increase upon the size reduction. Smaller particles have larger surface-to-volume ratios, resulting in more efficient quenching of the ${ }^{5} \mathrm{D}_{0}$ level and $\mathrm{Eu}^{3+}$ by the water molecules in an aqueous solution [42]. Comparing the quantum efficiencies of the ${ }^{5} \mathrm{D}_{0}$ level and $\mathrm{Eu}^{3+}$ luminescence quantum yields values, one can notice that the $\eta / \Phi$ ratio is equal to $0.5-0.9$, which indicates a very efficient energy transfer from initially excited terephthalate chromophore to the ${ }^{5} \mathrm{D}_{0}$ level of $\mathrm{Eu}^{3+}$ ion.

\subsection{Sensing Transition Metal Cations}

Previous studies demonstrated that the presence of impurities such as ions of transition metals $\left(\mathrm{Fe}^{3+}, \mathrm{Cu}^{2+}, \mathrm{Pb}^{2+}, \mathrm{MnO}_{4}{ }^{-}, \mathrm{Cr}_{2} \mathrm{O}_{7}{ }^{2-}\right)$ [43], and organic compounds (aromatic, nitroaromatic, carbonyl compounds) can significantly quench the luminescence of the Eu-based metal-organic frameworks [1-9] making them prospective for the design of luminescent sensors for various pollutants and explosives. To reveal the selectivity of the europium(III) terephthalate MOF luminescence quenching to the various metal cations, $80 \mu \mathrm{L}$ of aqueous suspensions of coarse-crystalline $\mathbf{1}\left(\mathrm{C}\left(\mathrm{Eu}^{3+}\right)=8 \mathrm{mM}\right)$ was mixed with the $100 \mu \mathrm{L}$ of metal salt solutions $\left(\mathrm{C}\left(\mathrm{M}^{\mathrm{n}+}\right)=100 \mathrm{mM} ; \mathrm{M}^{\mathrm{n}+}=\mathrm{Fe}^{3+}, \mathrm{Ca}^{2+}, \mathrm{Ba}^{2+}, \mathrm{Cr}^{3+}, \mathrm{Fe}^{2+}\right.$, $\left.\mathrm{Mg}^{2+}, \mathrm{Ni}^{2+}, \mathrm{Pb}^{2+}, \mathrm{Cu}^{2+}, \mathrm{Co}^{2+}, \mathrm{Zn}^{2+}, \mathrm{Cd}^{2+}\right)$ or distilled water. After $30 \mathrm{~min}$, the photographs of these solutions under $254 \mathrm{~nm}$ illumination were recorded (Figure 6a,b). It was found that the Eu-based red emission faded only in the presence of $\mathrm{Fe}^{3+}, \mathrm{Cr}^{3+}$ and $\mathrm{Cu}^{2+}$ ions (Figure 6a) starting from metal ion concentration 10-50 $\mathrm{mM}$ (Figure 6b). The emission spectra of aqueous solutions of nanocrystalline $3\left(\mathrm{C}\left(\mathrm{Eu}^{3+}\right)=5 \mu \mathrm{M}\right)$ in the absence and in the presence of various concentrations of $\mathrm{Cu}^{2+}, \mathrm{Cr}^{3+}$, and $\mathrm{Fe}^{3+}$ ions $\left(\lambda_{\text {exc }}=250 \mathrm{~nm}\right)$ indicate the quenching of $\mathrm{Eu}^{3+5} \mathrm{D}_{0}-{ }^{7} \mathrm{~F}_{\lambda}$ luminescence by the above-mentioned metal ions (Figure $6 \mathrm{c}-\mathrm{e}$ ). The dependence of the $615 \mathrm{~nm}$ emission band intensity on the $\mathrm{Cu}^{2+}, \mathrm{Cr}^{3+}$, and $\mathrm{Fe}^{3+}$ concentration is given in Figure 6f. The concentration dependence resembles the step-function, where luminescence intensity sharply falls starting from the certain concentration of metal ion: $1 \mu \mathrm{M}$ of $\mathrm{Cu}^{2+}$ and $30 \mu \mathrm{M}$ of $\mathrm{Cr}^{3+}$ or $\mathrm{Fe}^{3+}$. Surprisingly, we revealed that the addition of $\mathrm{Fe}^{3+}$ ions resulted in simultaneous quenching for the $\mathrm{Eu}^{3+5} \mathrm{D}_{0}-{ }^{7} \mathrm{~F}_{\lambda}$ luminescence (591, 615 , and $697 \mathrm{~nm}$ bands) and the terephthalate phosphorescence $(420 \mathrm{~nm})$, whereas the addition of $\mathrm{Cu}^{2+}$ and $\mathrm{Cr}^{3+}$ ions almost failed to reduce the intensity of the terephthalate phosphorescence band at $420 \mathrm{~nm}$ (Figures S1-S3, Supplementary Materials). This observation indicates a different quenching mechanism of $\mathrm{Eu}^{3+5} \mathrm{D}_{0}{ }^{7} \mathrm{~F}_{\lambda}$ luminescence by the above-mentioned metal ions. Most likely, $\mathrm{Cu}^{2+}, \mathrm{Cr}^{3+}$, and $\mathrm{Fe}^{3+}$ ions somehow coordinate with the oxygens of terephthalate ligands, but $\mathrm{Fe}^{3+}$ ions quench the ${ }^{3} \pi \pi^{*}$ triplet electronic excited state of terephthalate ion, whereas $\mathrm{Cu}^{2+}$ and $\mathrm{Cr}^{3+}$ ions quench the ${ }^{5} \mathrm{D}_{0}$ level of $\mathrm{Eu}^{3+}$. To reveal the complete quenching mechanism, one must study the excited-state dynamics of singlet and triplet electronic states of terephthalate ion, as well as the ${ }^{5} \mathrm{D}_{0}$ level of $\mathrm{Eu}^{3+}$, depending on the heavy metal ion concentration by time-resolved transient absorption and luminescence spectroscopy methods. We have found that nanocrystalline europium(III) terephthalate MOF 3 demonstrates significantly lower limits of detection on $\mathrm{Cu}^{2+}, \mathrm{Cr}^{3+}$, and $\mathrm{Fe}^{3+}$ ions than coarse-crystalline $\mathbf{1}(10-50 \mathrm{mM}$ for coarse-crystalline $1 \mathrm{vs} 1-30 \mu \mathrm{M}$ for 
nanocrystalline 3, Figure $6 \mathrm{~b}, \mathrm{f})$. This observation is explained by a larger surface-to-volume ratio of nanoparticles relatively to the bulk material, resulting in a higher luminescence quenching efficiency of the later materials due to a greater number of coordination sites. The sensitivity of our materials to $\mathrm{Cu}^{2+}, \mathrm{Cr}^{3+}$ and $\mathrm{Fe}^{3+}$ ions is comparable with the best reported luminescent MOF-based sensors reported previously (Table 4). Despite the higher sensitivity of electrochemical MOF-based sensors (Table 4), the luminescent sensors can be used for the design of relatively inexpensive express tests on heavy metal ions.

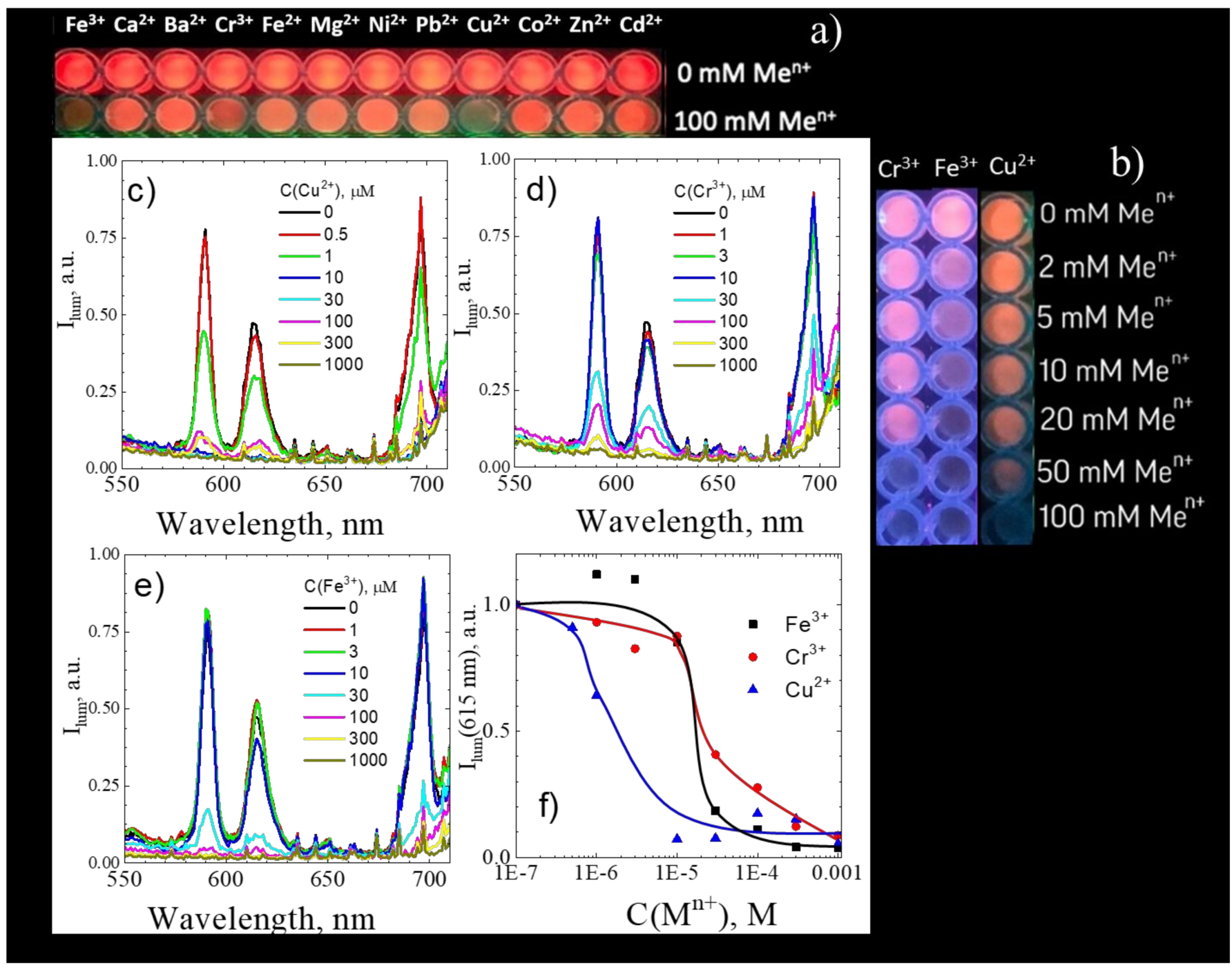

Figure 6. (a,b) Photographs of aqueous suspension of coarse-crystalline $\mathbf{1}$ under $254 \mathrm{~nm}$ illumination in the absence and presence of various metal ions; emission spectra of aqueous solution of nanocrystalline 3 in the absence and presence of various concentrations of $\mathrm{Cu}^{2+}(\mathbf{c}), \mathrm{Cr}^{3+}(\mathbf{d})$, and $\mathrm{Fe}^{3+}(\mathbf{e})$ ions upon $250 \mathrm{~nm}$ excitation; (f) $\mathrm{Cu}^{2+}, \mathrm{Cr}^{3+}$, and $\mathrm{Fe}^{3+}$ concentration dependence of $615 \mathrm{~nm}$ emission intensity of Sample 3.

Table 4. Limits of detection (LOD) of nanocrystalline europium(III) terephthalate tetrahydrate 3 and previously reported materials for $\mathrm{Cu}^{2+}, \mathrm{Cr}^{3+}$ and $\mathrm{Fe}^{3+}$ ions.

\begin{tabular}{ccccc}
\hline Sensing Material & Method & Target Contaminant & LOD & Ref. \\
\hline $\mathrm{Eu}_{2}(\mathrm{bdc})_{3} \cdot 4 \mathrm{H}_{2} \mathrm{O}$ & luminescent & $\mathrm{Cu}^{2+}$ & $1 \mu \mathrm{M}$ & Current work \\
$\mathrm{Tb}(\mathrm{BTC})\left(\mathrm{H}_{2} \mathrm{O}\right)$ & luminescent & $\mathrm{Cu}^{2+}$ & $10 \mu \mathrm{M}$ & {$[2]$} \\
$\mathrm{CDs} @ \mathrm{Eu}-\mathrm{DPA} \mathrm{MOF}$ & luminescent & $\mathrm{Cu}^{2+}$ & $26.3 \mathrm{nM}$ & {$[3,43]$} \\
{$\left[\mathrm{Eu}(\mathrm{PDC})_{1.5}(\mathrm{DMF})\right] \cdot(\mathrm{DMF})_{0.5}\left(\mathrm{H}_{2} \mathrm{O}\right)_{0.5}$} & luminescent & $\mathrm{Cu}^{2+}$ & $10 \mathrm{mM}$ & {$[7,44]$} \\
$\mathrm{Eu}_{2}(\mathrm{FMA})_{2}(\mathrm{OX})\left(\mathrm{H}_{2} \mathrm{O}\right)_{4} \cdot 4 \mathrm{H}_{2} \mathrm{O}$ & luminescent & $\mathrm{Cu}^{2+}$ & $100 \mu \mathrm{M}$ & {$[7,45]$} \\
\hline
\end{tabular}


Table 4. Cont.

\begin{tabular}{|c|c|c|c|c|}
\hline Sensing Material & Method & Target Contaminant & LOD & Ref. \\
\hline$\left[\mathrm{Eu}_{4}(\mathrm{BPT})_{4}(\mathrm{DMF})_{2}\left(\mathrm{H}_{2} \mathrm{O}\right)_{8}\right]$ & luminescent & $\mathrm{Cu}^{2+}$ & $10 \mu \mathrm{M}$ & {$[7,46]$} \\
\hline$\left[\mathrm{Tb}_{3}(\mathrm{~L})_{2}(\mathrm{HCOO})\left(\mathrm{H}_{2} \mathrm{O}\right)_{5}\right] \cdot \mathrm{DMF} \cdot 4 \mathrm{H}_{2} \mathrm{O}$ & luminescent & $\mathrm{Cu}^{2+}$ & $100 \mu \mathrm{M}$ & {$[7,47]$} \\
\hline$\left[\mathrm{Eu}(\mathrm{ox})_{2}\left(\mathrm{H}_{2} \mathrm{O}\right)\right]\left(\mathrm{Me}_{2} \mathrm{NH}_{2}\right)\left(\mathrm{H}_{2} \mathrm{O}\right)_{3}$ & luminescent & $\mathrm{Cu}^{2+}$ & $10 \mu \mathrm{M}$ & {$[10,48]$} \\
\hline $\mathrm{Zr}_{6}(\mathrm{O})_{8}\left(\mathrm{OH}_{2}\right)_{8}(\mathrm{tpdc})_{4}$ & luminescent & $\mathrm{Cu}^{2+}$ & $1 \mu \mathrm{M}$ & {$[10,49]$} \\
\hline PCN-222-Pd(II) & luminescent & $\mathrm{Cu}^{2+}$ & $50 \mathrm{nM}$ & {$[10,50]$} \\
\hline $\mathrm{Me}_{2} \mathrm{NH}_{2} @ \mathrm{MOF}-1$ & electrochemical & $\mathrm{Cu}^{2+}$ & $10 \mathrm{pM}$ & {$[3,51]$} \\
\hline $\mathrm{Eu}_{2}(\mathrm{bdc})_{3}$ nanoparticles & luminescent & $\mathrm{Fe}^{3+}$ & $30 \mu \mathrm{M}$ & Current work \\
\hline$\left[\mathrm{Me}_{2} \mathrm{NH}_{2}\right][\operatorname{In}(\mathrm{abtc})] \cdot$ solvents & luminescent & $\mathrm{Fe}^{3+}$ & $34.5 \mu \mathrm{M}$ & [52] \\
\hline$\left[\mathrm{LnK}(\mathrm{BPDSDC})(\mathrm{DMF})\left(\mathrm{H}_{2} \mathrm{O}\right)\right] \cdot x($ solvent $)$ & luminescent & $\mathrm{Fe}^{3+}$ & $10 \mu \mathrm{M}$ & {$[10,53]$} \\
\hline$\left[\mathrm{Eu}(\mathrm{BTPCA})\left(\mathrm{H}_{2} \mathrm{O}\right)\right] \cdot 2 \mathrm{DMF} \cdot 3 \mathrm{H}_{2} \mathrm{O}$ & luminescent & $\mathrm{Fe}^{3+}$ & $10 \mu \mathrm{M}$ & {$[7,54]$} \\
\hline$\left[\mathrm{Eu}(\mathrm{HL})\left(\mathrm{H}_{2} \mathrm{O}\right)_{2}\right]_{n} \cdot 2 \mathrm{H}_{2} \mathrm{O}$ & luminescent & $\mathrm{Fe}^{3+}$ & $1 \mu \mathrm{M}$ & {$[7,55]$} \\
\hline EuL & luminescent & $\mathrm{Fe}^{3+}$ & $100 \mu \mathrm{M}$ & {$[7,56]$} \\
\hline$\left[\mathrm{H}_{2} \mathrm{NMe}_{2}\right]_{3}\left[\mathrm{~Tb}(\mathrm{DPA})_{3}\right]$ & luminescent & $\mathrm{Fe}^{3+}$ & $10 \mu \mathrm{M}$ & {$[7,57]$} \\
\hline $\begin{array}{c}\text { Eu }\left(4^{\prime} \text {-(4-carboxyphenyl)-2,2': }\right. \\
\left.6^{\prime}, 2^{\prime \prime} \text {-terpyridine }\right)_{3}\end{array}$ & luminescent & $\mathrm{Fe}^{3+}$ & $100 \mu \mathrm{M}$ & {$[7,58]$} \\
\hline$\left[\mathrm{H}\left(\mathrm{H}_{2} \mathrm{O}\right)_{8}\right]\left[\mathrm{DyZn}_{4}(\mathrm{imdc})_{4}(\mathrm{im})_{4}\right]$ & luminescent & $\mathrm{Fe}^{3+}$ & $1 \mathrm{mM}$ & {$[7,59]$} \\
\hline $\mathrm{Eu}^{3+} @ \mathrm{Ga}_{2}(\mathrm{OH})_{4}\left(\mathrm{C}_{9} \mathrm{O}_{6} \mathrm{H}_{4}\right)$ & luminescent & $\mathrm{Fe}^{3+}$ & $0.28 \mu \mathrm{M}$ & {$[7,60]$} \\
\hline $\mathrm{nTbL}$ & luminescent & $\mathrm{Fe}^{3+}$ & $10 \mu \mathrm{M}$ & {$[7,61]$} \\
\hline$\left[\mathrm{Eu}(\text { atpt })_{1.5}(\text { phen })\left(\mathrm{H}_{2} \mathrm{O}\right)\right]_{\mathrm{n}}$ & luminescent & $\mathrm{Fe}^{3+}$ & $500 \mu \mathrm{M}$ & {$[7,62]$} \\
\hline$\left[(\mathrm{CH} 3)_{2} \mathrm{NH}_{2}\right] \cdot[\mathrm{Tb}(\mathrm{bptc})] \cdot \mathrm{xS}$ & luminescent & $\mathrm{Fe}^{3+}$ & $10 \mu \mathrm{M}$ & {$[7,63]$} \\
\hline Tb-BTB & luminescent & $\mathrm{Fe}^{3+}$ & $10 \mu \mathrm{M}$ & {$[7,64]$} \\
\hline$\left[\mathrm{Eu}_{3}(\mathrm{BDC})_{4.5}\left(\mathrm{H}_{2} \mathrm{O}\right)(\mathrm{DMF})_{2}\right]$ & luminescent & $\mathrm{Fe}^{3+}$ & $1 \mu \mathrm{M}$ & {$[7,65]$} \\
\hline$[\mathrm{Cd}(\mathrm{L})(\mathrm{BPDC})] \cdot 2 \mathrm{H}_{2} \mathrm{O}$ & luminescent & $\mathrm{Fe}^{3+}$ & $2 \mu \mathrm{M}$ & {$[8,66]$} \\
\hline$\left[\mathrm{Cd}(\mathrm{L})(\mathrm{SDBA})\left(\mathrm{H}_{2} \mathrm{O}\right)\right] \cdot 0.5 \mathrm{H}_{2} \mathrm{O}$ & luminescent & $\mathrm{Fe}^{3+}$ & $2 \mu \mathrm{M}$ & {$[8,66]$} \\
\hline$\left[\mathrm{Zn} 5(\text { hfipbb })_{4}(\operatorname{trz})_{2}\left(\mathrm{H}_{2} \mathrm{O}\right)_{2}\right]$ & luminescent & $\mathrm{Fe}^{3+}$ & $10 \mu \mathrm{M}$ & {$[8,67]$} \\
\hline$\left[\mathrm{Eu}(\mathrm{Hpzbc})_{2}\left(\mathrm{NO}_{3}\right)\right] \cdot \mathrm{H}_{2} \mathrm{O}$ & luminescent & $\mathrm{Fe}^{3+}$ & $10 \mu \mathrm{M}$ & {$[8,68]$} \\
\hline$\left[\mathrm{Eu}(\mathrm{L})\left(\mathrm{H}_{2} \mathrm{O}\right)_{2}\right] \cdot \mathrm{NMP} \cdot \mathrm{H}_{2} \mathrm{O}$ & luminescent & $\mathrm{Fe}^{3+}$ & $100 \mathrm{nM}$ & {$[8,69]$} \\
\hline$\left[\mathrm{Tb}(\mathrm{L} 1)_{1.5}\left(\mathrm{H}_{2} \mathrm{O}\right)\right] \cdot 3 \mathrm{H}_{2} \mathrm{O}$ & luminescent & $\mathrm{Fe}^{3+}$ & $10 \mu \mathrm{M}$ & {$[10,70]$} \\
\hline Bisdiene macrocycle & luminescent & $\mathrm{Fe}^{3+}$ & $0.58 \mu \mathrm{M}$ & [71] \\
\hline $\begin{array}{l}\text { 2-(cyclohexylamino)-3-phenyl-4Hfuro } \\
{[3,2-c] \text { chromen-4-one }}\end{array}$ & luminescent & $\mathrm{Fe}^{3+}$ & $1.73 \mu \mathrm{M}$ & [72] \\
\hline$\left[\mathrm{Me}_{2} \mathrm{NH}_{2}\right][\operatorname{In}(\mathrm{abtc})] \cdot$ solvents & luminescent & $\mathrm{Fe}^{3+}$ & $34.5 \mu \mathrm{M}$ & [53] \\
\hline $\mathrm{PPCOT} / \mathrm{NiFe}_{2} \mathrm{O}_{4} / \mathrm{C}-\mathrm{SWCNT}$ & electrochemical & $\mathrm{Fe}^{3+}$ & $100 \mathrm{pM}$ & [73] \\
\hline $\mathrm{Eu}_{2}(\mathrm{bdc})_{3}$ nanoparticles & luminescent & $\mathrm{Cr}^{3+}$ & $30 \mu \mathrm{M}$ & Current work \\
\hline $\mathrm{Tb}(\mathrm{BTC})\left(\mathrm{H}_{2} \mathrm{O}\right)$ & luminescent & $\mathrm{Cr}^{3+}$ & $10 \mu \mathrm{M}$ & {$[2]$} \\
\hline$\left[\mathrm{TbK}(\mathrm{BPDSDC})(\mathrm{DMF})\left(\mathrm{H}_{2} \mathrm{O}\right)_{2}\right]$ & & & $10 \mu \mathrm{M}$ & {$[8,74]$} \\
\hline$\left[\mathrm{Eu}_{2} \mathrm{~L}_{3}(\mathrm{DMF})_{3}\right] \cdot 2 \mathrm{DMF} \cdot 5 \mathrm{H}_{2} \mathrm{O}$ & luminescent & $\mathrm{Cr}^{3+}$ & $75.2 \mathrm{nM}$ & [75] \\
\hline ATNA deriviative & electrochemical & $\mathrm{Cr}^{3+}$ & $130 \mathrm{pM}$ & [76] \\
\hline
\end{tabular}

\section{Conclusions}

In summary, we reported the ultrasound-assisted wet-chemical synthesis and characterization of luminescent coarse-, micro-, and nano-crystalline $\mathrm{Eu}_{2} \mathrm{bdc}_{3} \cdot 4 \mathrm{H}_{2} \mathrm{O} \mathrm{MOFs}$. The particles of coarse-crystalline $\mathrm{Eu}_{2} \mathrm{bdc}_{3} \cdot 4 \mathrm{H}_{2} \mathrm{O}$, which are synthesized by the mixing of sodium terephthalate and europium chloride aqueous solutions without ultrasound, are dendrimer-like microparticle assemblies with the average particle size of $120 \pm 30 \mu \mathrm{m}$. The microcrystalline MOFs were prepared by mixing sodium terephthalate and europium chloride aqueous solutions with the addition of PEG-6000 in the presence of ultrasonication. The microparticles have the shape of leaf-like plates and an average size of $7.1 \times 2.8 \mu \mathrm{m}$. The average size of $\mathrm{Eu}_{2} \mathrm{bdc}_{3} \cdot 4 \mathrm{H}_{2} \mathrm{O}$ nanoparticles, synthesized by the mixing of low-concentration sodium terephthalate and europium chloride aqueous solutions in the presence of ultrasonication, is equal to about $8 \pm 2 \mathrm{~nm}$. Thus, the reported $\mathrm{Eu}_{2} \mathrm{bdc}_{3} \cdot 4 \mathrm{H}_{2} \mathrm{O}$ nanoparticles are the smallest nanosized rare-earth-based MOF crystals, to the best of our knowledge. The emission spectra of synthesized materials exhibit narrow lines corresponding to transitions from excited ${ }^{5} \mathrm{D}_{0}$ to lower ${ }^{7} \mathrm{~F}_{\mathrm{J}}$ levels of $\mathrm{Eu}^{3+}$ ion: ${ }^{5} \mathrm{D}_{0}{ }^{7} \mathrm{~F}_{0}(578 \mathrm{~nm}),{ }^{5} \mathrm{D}_{0}-{ }^{7} \mathrm{~F}_{1}(590 \mathrm{~nm}),{ }^{5} \mathrm{D}_{0}{ }^{-}{ }^{7} \mathrm{~F}_{2}$ 
$(615 \mathrm{~nm}),{ }^{5} \mathrm{D}_{0}-{ }^{7} \mathrm{~F}_{3}(649 \mathrm{~nm})$, and ${ }^{5} \mathrm{D}_{0}{ }^{7} \mathrm{~F}_{4}(697 \mathrm{~nm})$. Size reduction resulted in a broadening of the emission bands. The Eu ${ }^{3+}$ luminescence quantum yields, upon excitation into ${ }^{1} \pi \pi^{*}$ singlet electronic excited state of terephthalate ion, were found to be of $10 \pm 1 \%, 5 \pm 1 \%$ and $1.5 \pm 0.5 \%$ for coarse-, micro- and nanocrystalline $\mathrm{Eu}_{2} \mathrm{bdc}_{3} \cdot 4 \mathrm{H}_{2} \mathrm{O} \mathrm{MOFs}$, respectively. The nonradiative decay rate of nanocrystalline europium(III) terephthalate was significantly larger that the corresponding values of $\mathrm{Eu}_{2} \mathrm{bdc}_{3} \cdot 4 \mathrm{H}_{2} \mathrm{O}$ MOFs, which resulted from more efficient quenching of the ${ }^{5} \mathrm{D}_{0}$ level and $\mathrm{Eu}^{3+}$ by the water molecules in aqueous solution due to greater surface-to-volume ratio of nanocrystalline MOF. The $\mathrm{Cu}^{2+}, \mathrm{Cr}^{3+}$, and $\mathrm{Fe}^{3+}$ ions efficiently and selectively quench the $\mathrm{Eu}^{3+}{ }^{5} \mathrm{D}_{0}-{ }^{7} \mathrm{~F}_{\lambda}$ luminescence of nanocrystalline $\mathrm{Eu}_{2} \mathrm{bdc}_{3} \cdot 4 \mathrm{H}_{2} \mathrm{O} \mathrm{MOF}$ starting from the relatively low concentrations of metal ion: $1 \mu \mathrm{M}$ of $\mathrm{Cu}^{2+}$ and $30 \mu \mathrm{M}$ of $\mathrm{Cr}^{3+}$ or $\mathrm{Fe}^{3+}$. The reported nanocrystalline europium(III) terephthalateis one of the most sensitive luminescent MOF-based sensorfor $\mathrm{Cu}^{2+}, \mathrm{Cr}^{3+}$ and $\mathrm{Fe}^{3+}$ ions (Table 4). Therefore, synthesized nanocrystalline $\mathrm{Eu}_{2} \mathrm{bdc}_{3} \cdot 4 \mathrm{H}_{2} \mathrm{O}$ MOFs can be considered promising luminescent probes for heavy metal ions in waste and drinking water.

Supplementary Materials: The following are available online at https://www.mdpi.com/article/10 $.3390 /$ nano11092448/s1, Figure S1: (a) Emission spectra of aqueous solution of nanocrystalline 3 in the absence and presence of various concentrations of $\mathrm{Cu}^{2+}$ upon $250 \mathrm{~nm}$ excitation; (b) $\mathrm{Cu}^{2+}$ concentration dependence of 420,591, 615, and $697 \mathrm{~nm}$ emission intensities of 3, Figure S2: (a) Emission spectra of aqueous solution of nanocrystalline 3 in the absence and presence of various concentrations of $\mathrm{Cr}^{3+}$ upon $250 \mathrm{~nm}$ excitation; (b) $\mathrm{Cr}^{3+}$ concentration dependence of 420, 591, 615, and $697 \mathrm{~nm}$ emission intensities of 3, Figure S3: (a) Emission spectra of aqueous solution of nanocrystalline 3 in the absence and presence of various concentrations of $\mathrm{Fe}^{3+}$ upon $250 \mathrm{~nm}$ excitation; (b) $\mathrm{Fe}^{3+}$ concentration dependence of 420,591,615, and $697 \mathrm{~nm}$ emission intensities of 3.

Author Contributions: Conceptualization, S.S.K., E.M.K. and A.S.M.; Methodology, S.S.K. and E.M.K.; Formal Analysis, A.S.M., V.G.N. and I.E.K.; Investigation, S.S.K., V.G.N., I.E.K., E.M.K., A.A.V. and A.A.S.; Resources, N.A.B., M.Y.S. and A.S.M.; Data Curation, A.S.M. and I.E.K., Writing-Original Draft Preparation, A.S.M. and V.G.N.; Writing-Review and Editing, M.N.R., M.S.P., I.I.T., N.A.B. and M.Y.S.; Visualization, V.D.K.; Supervision, A.S.M.; Project Administration, A.S.M.; Funding Acquisition, A.S.M. and M.S.P. All authors have read and agreed to the published version of the manuscript.

Funding: The reported study was funded by the Russian Fund for Basic Research (RFBR), project number 20-33-70025 (A.S.M., N.A.B. and M.Y.S.). The work was partially supported by Ministry of Education and Science of the Russian Federation (project FSRM-2020-0006, M.S.P. and M.N.R.). The visit of A.S.M., V.G.N., A.A.V., A.A.S., I.I.T., N.A.B. and M.Y.S. to the Educational Center "Sirius" was funded by Educational Foundation "Talent and Success".

Data Availability Statement: Data is contained within this article and corresponding supplementary materials.

Acknowledgments: The measurements were performed at the Research Park of Saint Petersburg State University ("Magnetic Resonance Research Centre", "SPbU Computing Centre", "Cryogenic Department", "Interdisciplinary Resource Centre for Nanotechnology", "Centre for X-ray Diffraction Studies", "Chemical Analysis and Materials Research Centre", "Centre for Optical and Laser Materials Research", and "Centre for Innovative Technologies of Composite Nanomaterials"). The project was partially performed at the facilities of the Educational Center "Sirius", Sochi, Russia. The authors acknowledge Elena A. Bessonova, Vladimir Sosnovsky, David Zheglov, Anton Ostrosablin, and Saveliy Zaverukhin for help with the experiments.

Conflicts of Interest: The authors declare no conflict of interest.

\section{References}

1. Zeng, X.; Zhang, Y.; Zhang, J.; Hu, H.; Wu, X.; Long, Z.; Hou, X. Facile colorimetric sensing of Pb ${ }^{2+}$ using bimetallic lanthanide metal-organic frameworks as luminescent probe for field screen analysis of lead-polluted environmental water. Microchem. J. 2017, 134, 140-145. [CrossRef]

2. Cai, D.; Guo, H.; Wen, L.; Liu, C. Fabrication of hierarchical architectures of Tb-MOF by a "green coordination modulation method" for the sensing of heavy metal ions. CrystEngComm 2013, 15, 6702. [CrossRef]

3. Fang, X.; Zong, B.; Mao, S. Metal-Organic Framework-Based Sensors for Environmental Contaminant Sensing. Nano-Micro Lett. 2018, 10, 64. [CrossRef] [PubMed] 
4. Feng, H.-J.; Xu, L.; Liu, B.; Jiao, H. Europium metal-organic frameworks as recyclable and selective turn-off fluorescent sensors for aniline detection. Dalton Trans. 2016, 45, 17392-17400. [CrossRef]

5. Xu, H.; Liu, F.; Cui, Y.; Chen, B.; Qian, G. A luminescent nanoscale metal-organic framework for sensing of nitroaromatic explosives. Chem. Commun. 2011, 47, 3153. [CrossRef]

6. Crawford, S.E.; Ohodnicki, P.R.; Baltrus, J.P. Materials for the photoluminescent sensing of rare earth elements: Challenges and opportunities. J. Mater. Chem. C 2020, 8, 7975-8006. [CrossRef]

7. Mahata, P.; Mondal, S.K.; Singha, D.K.; Majee, P. Luminescent rare-earth-based MOFs as optical sensors. Dalton Trans. 2017, 46, 301-328. [CrossRef]

8. Zhang, Y.; Yuan, S.; Day, G.; Wang, X.; Yang, X.; Zhou, H.-C. Luminescent sensors based on metal-organic frameworks. Coord. Chem. Rev. 2018, 354, 28-45. [CrossRef]

9. Zhang, X.; Kang, X.; Cui, W.; Zhang, Q.; Zheng, Z.; Cui, X. Floral and lamellar europium(III)-based metal-organic frameworks as high sensitivity luminescence sensors for acetone. New J. Chem. 2019, 43, 8363-8369. [CrossRef]

10. Lustig, W.P.; Mukherjee, S.; Rudd, N.D.; Desai, A.V.; Li, J.; Ghosh, S.K. Metal-organic frameworks: Functional luminescent and photonic materials for sensing applications. Chem. Soc. Rev. 2017, 46, 3242-3285. [CrossRef]

11. Adusumalli, V.N.K.B.; Runowski, M.; Lis, S. 3,5-dihydroxy benzoic acid-capped caf2: $\mathrm{Tb}^{3+}$ nanocrystals as luminescent probes for the wo42- ion in aqueous solution. ACS Omega 2020, 5, 4568-4575. [CrossRef]

12. Aslandukov, A.N.; Utochnikova, V.V.; Goriachiy, D.O.; Vashchenko, A.A.; Tsymbarenko, D.M.; Hoffmann, M.; Pietraszkiewicz, M.; Kuzmina, N.P. The development of a new approach toward lanthanide-based OLED fabrication: New host materials for Tb-based emitters. Dalton Trans. 2018, 47, 16350-16357. [CrossRef]

13. Liu, D.; Lu, K.; Poon, C.; Lin, W. Metal-organic Frameworks as Sensory Materials and Imaging Agents. Inorg. Chem. 2014, 53, 1916-1924. [CrossRef]

14. Younis, S.A.; Bhardwaj, N.; Bhardwaj, S.K.; Kim, K.-H.; Deep, A. Rare earth metal-organic frameworks (RE-MOFs): Synthesis, properties, and biomedical applications. Coord. Chem. Rev. 2021, 429, 213620. [CrossRef]

15. Zhou, X.; Wang, H.; Jiang, S.; Xiang, G.; Tang, X.; Luo, X.; Li, L.; Zhou, X. Multifunctional Luminescent Material Eu(III) and Tb(III) Complexes with Pyridine-3,5-Dicarboxylic Acid Linker: Crystal Structures, Tunable Emission, Energy Transfer, and Temperature Sensing. Inorg. Chem. 2019, 58, 3780-3788. [CrossRef] [PubMed]

16. Khudoleeva, V.; Tcelykh, L.; Kovalenko, A.; Kalyakina, A.; Goloveshkin, A.; Lepnev, L.; Utochnikova, V. Terbium-europium fluorides surface modified with benzoate and terephthalate anions for temperature sensing: Does sensitivity depend on the ligand? J. Lumin. 2018, 201, 500-508. [CrossRef]

17. Dou, X.; Sun, K.; Chen, H.; Jiang, Y.; Wu, L.; Mei, J.; Ding, Z.; Xie, J. Nanoscale metal-organic frameworks as fluorescence sensors for food safety. Antibiotics 2021, 10, 358. [CrossRef] [PubMed]

18. Puglisi, R.; Pellegrino, A.L.; Fiorenza, R.; Scirè, S.; Malandrino, G. A facile one-pot approach to the synthesis of gd-eu based metal-organic frameworks and applications to sensing of $\mathrm{Fe}^{3+}$ and $\mathrm{Cr}_{2} \mathrm{O}_{7}{ }^{2-}$ ions. Sensors 2021, 21, 1679. [CrossRef] [PubMed]

19. Ding, S.B.; Wang, W.; Qiu, L.G.; Yuan, Y.P.; Peng, F.M.; Jiang, X.; Xie, A.J.; Shen, Y.H.; Zhu, J.F. Surfactant-assisted synthesis of lanthanide metal-organic framework nanorods and their fluorescence sensing of nitroaromatic explosives. Mater. Lett. 2011, 65, 1385-1387. [CrossRef]

20. Li, Q.; Liu, H.; Alattar, M.; Jiang, S.; Han, J.; Ma, Y.; Jiang, C. The preferential accumulation of heavy metals in different tissues following frequent respiratory exposure to PM2.5 in rats. Sci. Rep. 2015, 5, 16936. [CrossRef]

21. Jaishankar, M.; Tseten, T.; Anbalagan, N.; Mathew, B.B.; Beeregowda, K.N. Toxicity, mechanism and health effects of some heavy metals. Interdiscip. Toxicol. 2014, 7, 60-72. [CrossRef]

22. Daiguebonne, C.; Kerbellec, N.; Guillou, O.; Bünzli, J.-C.; Gumy, F.; Catala, L.; Mallah, T.; Audebrand, N.; Gérault, Y.; Bernot, K.; et al. Structural and Luminescent Properties of Micro- and Nanosized Particles of Lanthanide Terephthalate Coordination Polymers. Inorg. Chem. 2008, 47, 3700-3708. [CrossRef]

23. Zou, H.; Wang, L.; Zeng, C.; Gao, X.; Wang, Q.; Zhong, S. Rare-earth coordination polymer micro/nanomaterials: Preparation, properties and applications. Front. Mater. Sci. 2018, 12, 327-347. [CrossRef]

24. Escudero, A.; Becerro, A.I.; Carrillo-carrión, C.; Núñez, N.O.; Zyuzin, M.V.; Laguna, M.; González-mancebo, D.; Ocaña, M.; Parak, W.J. Rare earth based nanostructured materials: Synthesis, functionalization, properties and bioimaging and biosensing applications. Nanophotonics 2017, 6, 881-921. [CrossRef]

25. Wang, F.; Deng, K.; Wu, G.; Liao, H.; Liao, H.; Zhang, L.; Lan, S.; Zhang, J.; Song, X.; Wen, L. Facile and Large-Scale Syntheses of Nanocrystal Rare Earth Metal-organic Frameworks at Room Temperature and Their Photoluminescence Properties. J. Inorg. Organomet. Polym. Mater. 2012, 22, 680-685. [CrossRef]

26. Yang, G.; Lin, W.; Lai, H.; Tong, J.; Lei, J.; Yuan, M.; Zhang, Y.; Cui, C. Ultrasonics Sonochemistry Understanding the relationship between particle size and ultrasonic treatment during the synthesis of metal nanoparticles. Ultrason. Sonochem. 2021, $73,105497$. [CrossRef] [PubMed]

27. Liu, W.; Yin, R.; Xu, X.; Zhang, L.; Shi, W.; Cao, X. Structural Engineering of Low-Dimensional Metal-organic Frameworks: Synthesis, Properties, and Applications. Adv. Sci. 2019, 6, 1802373. [CrossRef] [PubMed]

28. Taylor, K.M.L.; Jin, A.; Lin, W. Surfactant-Assisted Synthesis of Nanoscale Gadolinium Metal-Organic Frameworks for Potential Multimodal Imaging. Angew. Chem. Int. Ed. 2008, 47, 7722-7725. [CrossRef] [PubMed] 
29. Pellegrino, F.; Sordello, F.; Mino, L.; Prozzi, M.; Mansfeld, U.; Hodoroaba, V.-D.; Minero, C. Polyethylene Glycol as Shape and Size Controller for the Hydrothermal Synthesis of $\mathrm{SrTiO}_{3}$ Cubes and Polyhedra. Nanomaterials 2020, 10, 1892. [CrossRef] [PubMed]

30. Yeung, H.H.M.; Sapnik, A.F.; Massingberd-Mundy, F.; Gaultois, M.W.; Wu, Y.; Fraser, D.A.X.; Henke, S.; Pallach, R.; Heidenreich, N.; Magdysyuk, O.V.; et al. Control of Metal-organic Framework Crystallization by Metastable Intermediate Pre-equilibrium Species. Angew. Chem. Int. Ed. 2019, 58, 566-571. [CrossRef] [PubMed]

31. Dighe, A.V.; Nemade, R.Y.; Singh, M.R. Modeling and Simulation of Crystallization of Metal-organic Frameworks. Processes 2019, 7, 527. [CrossRef]

32. Reineke, T.M.; Eddaoudi, M.; Fehr, M.; Kelley, D.; Yaghi, O.M. From Condensed Lanthanide Coordination Solids to Microporous Frameworks Having Accessible Metal Sites. J. Am. Chem. Soc. 1999, 121, 1651-1657. [CrossRef]

33. Shannon, R.D. Revised Effective Ionic Radii and Systematic Studies of Interatomie Distances in in Halides and Chaleogenides. Acta Crystallogr. Sect. A 1976, A32, 751-767. [CrossRef]

34. Haquin, V.; Etienne, M.; Daiguebonne, C.; Freslon, S.; Calvez, G.; Bernot, K.; Le Pollès, L.; Ashbrook, S.E.; Mitchell, M.R.; Bünzli, J.-C.; et al. Color and Brightness Tuning in Heteronuclear Lanthanide Terephthalate Coordination Polymers. Eur. J. Inorg. Chem. 2013, 2013, 3464-3476. [CrossRef]

35. Utochnikova, V.V.; Grishko, A.Y.; Koshelev, D.S.; Averin, A.A.; Lepnev, L.S.; Kuzmina, N.P. Lanthanide heterometallic terephthalates: Concentration quenching and the principles of the "multiphotonic emission". Opt. Mater. (Amst). 2017, 74, 201-208. [CrossRef]

36. Binnemans, K. Interpretation of europium(III) spectra. Coord. Chem. Rev. 2015, 295, 1-45. [CrossRef]

37. Carrera Jota, M.L.; García Murillo, A.; Carrillo Romo, F.; García Hernández, M.; Morales Ramírez, A.D.J.; Velumani, S.; de la Rosa Cruz, E.; Kassiba, A. $\mathrm{Lu}_{2} \mathrm{O}_{3}: \mathrm{Eu}^{3+}$ glass ceramic films: Synthesis, structural and spectroscopic studies. Mater. Res. Bull. 2014, 51, 418-425. [CrossRef]

38. Liu, G.; Hong, G.; Sun, D. Synthesis and characterization of $\mathrm{SiO}_{2} / \mathrm{Gd}_{2} \mathrm{O}_{3}$ :Eu core-shell luminescent materials. J. Colloid Interface Sci. 2004, 278, 133-138. [CrossRef]

39. Kolesnikov, I.; Povolotskiy, A.; Mamonova, D.; Lahderanta, E.; Manshina, A.; Mikhailov, M. Photoluminescence Properties of $\mathrm{Eu}^{3+}$ Ions in Yttrium Oxide Nanoparticles: Defect vs Normal Sites. RSC Adv. 2016, 6, 76533-76541. [CrossRef]

40. Golyeva, E.V.; Kolesnikov, I.E.; Lähderanta, E.; Kurochkin, A.V.; Mikhailov, M.D. Effect of synthesis conditions on structural, morphological and luminescence properties of $\mathrm{MgAl}_{2} \mathrm{O}_{4}: \mathrm{Eu}^{3+}$ nanopowders. J. Lumin. 2018, 194, 387-393. [CrossRef]

41. Kolesnikov, I.E.; Kolokolov, D.S.; Kurochkin, M.A.; Voznesenskiy, M.A.; Osmolowsky, M.G.; Lähderanta, E.; Osmolovskaya, O.M. Morphology and doping concentration effect on the luminescence properties of $\mathrm{SnO}_{2}: \mathrm{Eu}^{3+}$ nanoparticles. J. Alloys Compd. 2020, 822, 153640. [CrossRef]

42. Gorbunov, A.O.; Lindqvist-Reis, P.; Mereshchenko, A.S.; Skripkin, M.Y. Solvation and complexation of europium(III) ions in triflate and chloride aqueous-organic solutions by TRLF spectroscopy. J. Mol. Liq. 2017, 240, 25-34. [CrossRef]

43. Hao, J.; Liu, F.; Liu, N.; Zeng, M.; Song, Y.; Wang, L. Ratiometric fluorescent detection of $\mathrm{Cu}^{2+}$ with carbon dots chelated Eu-based metal-organic frameworks. Sens. Actuators B Chem. 2017, 245, 641-647. [CrossRef]

44. Chen, B.; Wang, L.; Xiao, Y.; Fronczek, F.R.; Xue, M.; Cui, Y.; Qian, G. A luminescent metal-organic framework with Lewis basic pyridyl sites for the sensing of metal ions. Angew. Chem. Int. Ed. 2009, 48, 500-503. [CrossRef] [PubMed]

45. Xiao, Y.; Cui, Y.; Zheng, Q.; Xiang, S.; Qian, G.; Chen, B. A microporous luminescent metal-organic framework for highly selective and sensitive sensing of $\mathrm{Cu} 2+$ in aqueous solution. Chem. Commun. 2010, 46, 5503-5505. [CrossRef] [PubMed]

46. Hao, Z.; Yang, G.; Song, X.; Zhu, M.; Meng, X.; Zhao, S.; Song, S.; Zhang, H. A europium(III) based metal-organic framework: Bifunctional properties related to sensing and electronic conductivity. J. Mater. Chem. A 2014, 2, 237-244. [CrossRef]

47. Zhao, J.; Wang, Y.N.; Dong, W.W.; Wu, Y.P.; Li, D.S.; Zhang, Q.C. A Robust Luminescent Tb(III)-MOF with Lewis Basic Pyridyl Sites for the Highly Sensitive Detection of Metal Ions and Small Molecules. Inorg. Chem. 2016, 55, 3265-3271. [CrossRef] [PubMed]

48. Wang, X.; Qin, T.; Bao, S.S.; Zhang, Y.C.; Shen, X.; Zheng, L.M.; Zhu, D. Facile synthesis of a water stable 3D Eu-MOF showing high proton conductivity and its application as a sensitive luminescent sensor for $\mathrm{Cu}^{2+}$ ions. J. Mater. Chem. A 2016, 4, 16484-16489. [CrossRef]

49. Carboni, M.; Lin, Z.; Abney, C.W.; Zhang, T.; Lin, W. A metal-organic framework containing unusual eight-connected Zr-oxo secondary building units and orthogonal carboxylic acids for ultra-sensitive metal detection. Chem.-Eur. J. 2014, 20, 14965-14970. [CrossRef]

50. Chen, Y.Z.; Jiang, H.L. Porphyrinic Metal-Organic Framework Catalyzed Heck-Reaction: Fluorescence "turn-On" Sensing of $\mathrm{Cu}$ (II) Ion. Chem. Mater. 2016, 28, 6698-6704. [CrossRef]

51. Jin, J.-C.; Wu, J.; Yang, G.-P.; Wu, Y.-L.; Wang, Y.-Y. A microporous anionic metal-organic framework for a highly selective and sensitive electrochemical sensor of $\mathrm{Cu}^{2+}$ ions. Chem. Commun. 2016, 52, 8475-8478. [CrossRef]

52. Luo, Y.H.; Xie, A.D.; Chen, W.C.; Shen, D.; Zhang, D.E.; Tong, Z.W.; Lee, C.S. Multifunctional anionic indium-organic frameworks for organic dye separation, white-light emission and dual-emitting $\mathrm{Fe}^{3+}$ sensing. J. Mater. Chem. C 2019, 7, 14897-14903. [CrossRef]

53. Zhou, L.J.; Deng, W.H.; Wang, Y.L.; Xu, G.; Yin, S.G.; Liu, Q.Y. Lanthanide-Potassium Biphenyl-3,3'-disulfonyl-4,4'-dicarboxylate Frameworks: Gas Sorption, Proton Conductivity, and Luminescent Sensing of Metal Ions. Inorg. Chem. 2016, 55, 6271-6277. [CrossRef] 
54. Tang, Q.; Liu, S.; Liu, Y.; Miao, J.; Li, S.; Zhang, L.; Shi, Z.; Zheng, Z. Cation Sensing by a Luminescent Metal-organic Framework with Multiple Lewis Basic Sites. Inorg. Chem. 2013, 52, 2799-2801. [CrossRef] [PubMed]

55. Liang, Y.-T.; Yang, G.-P.; Liu, B.; Yan, Y.-T.; Xi, Z.-P.; Wang, Y.-Y. Four super water-stable lanthanide-organic frameworks with active uncoordinated carboxylic and pyridyl groups for selective luminescence sensing of $\mathrm{Fe}^{3+}$. Dalton Trans. 2015, 44, 13325-13330. [CrossRef] [PubMed]

56. Dang, S.; Ma, E.; Sun, Z.M.; Zhang, H. A layer-structured Eu-MOF as a highly selective fluorescent probe for Fe ${ }^{3+}$ detection through a cation-exchange approach. J. Mater. Chem. 2012, 22, 16920-16926. [CrossRef]

57. Weng, H.; Yan, B. Lanthanide coordination polymers for multi-color luminescence and sensing of Fe ${ }^{3+}$. Inorg. Chem. Commun. 2016, 63, 11-15. [CrossRef]

58. Zheng, M.; Tan, H.; Xie, Z.; Zhang, L.; Jing, X.; Sun, Z. Fast response and high sensitivity europium metal organic framework fluorescent probe with chelating terpyridine sites for $\mathrm{Fe}^{3+}$. ACS Appl. Mater. Interfaces 2013, 5, 1078-1083. [CrossRef]

59. Li, Y.F.; Wang, D.; Liao, Z.; Kang, Y.; Ding, W.H.; Zheng, X.J.; Jin, L.P. Luminescence tuning of the Dy-Zn metal-organic framework and its application in the detection of Fe(III) ions. J. Mater. Chem. C 2016, 4, 4211-4217. [CrossRef]

60. Xu, X.Y.; Yan, B. Eu(III)-functionalized MIL-124 as fluorescent probe for highly selectively sensing ions and organic small molecules especially for Fe(III) and Fe(II). ACS Appl. Mater. Interfaces 2015, 7, 721-729. [CrossRef]

61. Dang, S.; Wang, T.; Yi, F.; Liu, Q.; Yang, W.; Sun, Z.M. A Nanoscale Multiresponsive Luminescent Sensor Based on a Terbium(III) Metal-Organic Framework. Chem.-Asian J. 2015, 10, 1703-1709. [CrossRef]

62. Kang, Y.; Zheng, X.J.; Jin, L.P. A microscale multi-functional metal-organic framework as a fluorescence chemosensor for Fe(III), $\mathrm{Al}(\mathrm{III})$ and 2-hydroxy-1-naphthaldehyde. J. Colloid Interface Sci. 2016, 471, 1-6. [CrossRef]

63. Zhao, X.-L.; Tian, D.; Gao, Q.; Sun, H.-W.; Xu, J.; Bu, X.-H. A chiral lanthanide metal-organic framework for selective sensing of Fe( iii ) ions. Dalton Trans. 2016, 45, 1040-1046. [CrossRef]

64. Xu, H.; Hu, H.C.; Cao, C.S.; Zhao, B. Lanthanide Organic Framework as a Regenerable Luminescent Probe for Fe ${ }^{3+}$. Inorg. Chem. 2015, 54, 4585-4587. [CrossRef]

65. Zhao, J.J.; Liu, P.Y.; Dong, Z.P.; Liu, Z.L.; Wang, Y.Q. Eu(III)-organic framework as a multi-responsive photoluminescence sensor for efficient detection of 1-naphthol, $\mathrm{Fe}^{3+}$ and $\mathrm{MnO}^{4-}$ in water. Inorg. Chim. Acta 2020, 511, 119843. [CrossRef]

66. Chen, S.; Shi, Z.; Qin, L.; Jia, H.; Zheng, H. Two new luminescent Cd(II)-metal-organic frameworks as bifunctional chemosensors for detection of cations $\mathrm{Fe} 3+$, anions $\mathrm{CrO}_{4}{ }^{2-}$, and $\mathrm{Cr}_{2} \mathrm{O}_{7}{ }^{2-}$ in aqueous solution. Cryst. Growth Des. 2017, 17, 67-72. [CrossRef]

67. Hou, B.L.; Tian, D.; Liu, J.; Dong, L.Z.; Li, S.L.; Li, D.S.; Lan, Y.Q. A Water-Stable Metal-Organic Framework for Highly Sensitive and Selective Sensing of $\mathrm{Fe}^{3+}$ Ion. Inorg. Chem. 2016, 55, 10580-10586. [CrossRef] [PubMed]

68. Li, G.-P.; Liu, G.; Li, Y.-Z.; Hou, L.; Wang, Y.-Y.; Zhu, Z. Uncommon Pyrazoyl-Carboxyl Bifunctional Ligand-Based Microporous Lanthanide Systems: Sorption and Luminescent Sensing Properties. Inorg. Chem. 2016, 55, 3952-3959. [CrossRef]

69. Wen, G.X.; Wu, Y.P.; Dong, W.W.; Zhao, J.; Li, D.S.; Zhang, J. An Ultrastable Europium(III)-Organic Framework with the Capacity of Discriminating $\mathrm{Fe}^{2+} / \mathrm{Fe}^{3+}$ Ions in Various Solutions. Inorg. Chem. 2016, 55, 10114-10117. [CrossRef] [PubMed]

70. Cao, L.H.; Shi, F.; Zhang, W.M.; Zang, S.Q.; Mak, T.C.W. Selective Sensing of $\mathrm{Fe}^{3+}$ and $\mathrm{Al}^{3+}$ Ions and Detection of 2,4,6Trinitrophenol by a Water-Stable Terbium-Based Metal-Organic Framework. Chem. Eur. J. 2015, 21, 15705-15712. [CrossRef] [PubMed]

71. Qiu, L.; Zhu, C.; Chen, H.; Hu, M.; He, W.; Guo, Z. A turn-on fluorescent $\mathrm{Fe}^{3+}$ sensor derived from an anthracene-bearing bisdiene macrocycle and its intracellular imaging application. Chem. Commun. 2014, 50, 4631-4634. [CrossRef] [PubMed]

72. Sarih, N.M.; Ciupa, A.; Moss, S.; Myers, P.; Slater, A.G.; Abdullah, Z.; Tajuddin, H.A.; Maher, S. Furo[3,2-c]coumarin-derived Fe3+ Selective Fluorescence Sensor: Synthesis, Fluorescence Study and Application to Water Analysis. Sci. Rep. 2020, $10,7421$. [CrossRef]

73. Katowah, D.F.; Hussein, M.A.; Alam, M.M.; Ismail, S.H.; Osman, O.I.; Sobahi, T.R.; Asiri, A.M.; Ahmed, J.; Rahman, M.M. Designed network of ternary core-shell PPCOT/ $\mathrm{NiFe}_{2} \mathrm{O}_{4} / \mathrm{C}-\mathrm{SWCNTs}$ nanocomposites. A Selective Fe ${ }^{3+}$ ionic sensor. J. Alloys Compd. 2020, 834, 155020. [CrossRef]

74. Wang, H.H.; Zhou, L.J.; Wang, Y.L.; Liu, Q.Y. Terbium-biphenyl-3,3'-disulfonyl-4,4'-dicarboxylate framework with sulfonate sites for luminescent sensing of $\mathrm{Cr}^{3+}$ ion. Inorg. Chem. Commun. 2016, 73, 94-97. [CrossRef]

75. Zhang, P.-P.; Song, B.; Li, Z.; Zhang, J.-J.; Ni, A.-Y.; Chen, J.; Ni, J.; Liu, S.; Duan, C. A “turn-on" Cr ${ }^{3+}$ ion probe based on non-luminescent metal-organic framework-new strategy to prepare a recovery probe. J. Mater. Chem. A 2021, 9, 13552-13561. [CrossRef]

76. El-Shishtawy, R.M.; Rahman, M.M.; Sheikh, T.A.; Nadeem Arshad, M.; Al-Zahrani, F.A.M.; Asiri, A.M. A New Cr ${ }^{3+}$ Electrochemical Sensor Based on ATNA/Nafion/Glassy Carbon Electrode. Materials 2020, 13, 2695. [CrossRef] 